OECDpublishing

\title{
BARRIERS TO EXIT IN THE STEEL SECTOR
}

OECD SCIENCE, TECHNOLOGY AND INDUSTRY POLICY PAPERS

October 2020 No. 93 
This paper was authored by Michele Rimini, Anthony de Carvalho, Fabien Mercier and Valentina Burrai, from the OECD Directorate for Science, Technology and Innovation, Benjamin Liebman (Saint Joseph's University) and Timothy de Stefano (Harvard Business School). It was approved and declassified by written procedure by the OECD Steel Committee on 29 May 2020 and prepared for publication by the OECD Secretariat.

Note to Delegations:

This document is also available on O.N.E under the reference code: DSTI/SC(2O2O)16/FINAL

This document, as well as any data and any map included herein, are without prejudice to the status of or sovereignty over any territory, to the delimitation of international frontiers and boundaries and to the name of any territory, city or area.

(C) OECD 2020

The use of this work, whether digital or print, is governed by the Terms and Conditions to be found at http://www.oecd.org/termsandconditions. 


\section{Abstract}

This paper explores the nature of exit barriers in the steel industry, their social and economic implications, and policy approaches to deal with exits and steel industry restructuring. Barriers to exit in the steel industry require attention due to their negative impacts on excess capacity. Such barriers mainly stem from government interventions that hinder the closure of inefficient or unviable steel plants, though cost factors specific to the steel industry are important barriers, as well. Exits may also entail important costs associated with redundancy payments to workers, environmental clean-up and operations to dismantle mills. The paper concludes with specific policy recommendations to promote adjustment, including removing subsidies and other government support measures that maintain unviable plants, assisting displaced steel workers into other activities, and other measures to limit the social costs of steel plant closures.

Keywords: Barriers to exit, structural adjustment, subsidies and support measures, steel, steel excess capacity 


\section{Table of contents}

1. Introduction 6

2. Characteristics of exit in the steel industry 8

3. Barriers to exit 13

3.1. Subsidies and other government support measures 13

3.2. Factors that reduce competition $\quad 22$

\begin{tabular}{lr}
$3 \cdot 3$. & Cost considerations \\
\hline
\end{tabular}

4. Social, economic and geographic costs of closures 32

4.1. Earnings losses and employment duration 32

4.2. Geographic concentration and reallocation 33

4.3. Health and other social consequences $\quad 34$

5. Past policy approaches 36

5.1. Labour-market policies to address displaced workers 36

5.2. Examples of restructuring and policies relevant for exit 38

6. Possible policy recommendations for discussion 43

$\begin{array}{ll}\text { 7. Conclusions } & 47\end{array}$

$\begin{array}{ll}\text { References } & 48\end{array}$

\section{FIGURES}

Figure 1. Average exit rates among manufacturing industries, 2000-2015 8

Figure 2. Estimates of the probability of plant closure over time $\quad 9$

$\begin{array}{lr}\text { Figure 3. Estimates of the probability of plant closure over time by region } & 10\end{array}$

Figure 4. Estimates of the probability of plant closures by plant characteristics $\quad 11$

Figure 5. Estimates of the probability of plant closure by technology 12

Figure 6. Estimates of the probability of plant closures by Strictness of EPLs 29

Figure 7. Estimates of the probability of plant closures by EPS 31 


\section{TABLES}

Table 1. Potential effects of grants, awards and cost refunds on exit 15

Table 2. Potential effects of preferential loans and guarantees on exit 17

Table 3. Potential effects of equity infusions, conversions and debt forgiveness on exit 18

Table 4. Potential effects of tax benefits on exit

Table 5. Potential effects of input support on exit

Table 6. Potential effects of various forms of output support on exit 


\section{Introduction}

Addressing excess capacity in the steel sector is amongst the highest of policy priorities for many OECD and steel producing economies around the world. A major source of excess capacity stems from the lack of market-driven exit from the steel sector due to government support measures that keep inefficient capacity in the marketplace. Steelmaking capacity that would not be viable without government support or special conditions should be taken out of the market, freeing up resources to be used in more productive economic activities. However, given the economic and strategic importance of the steel sector, subsidies and other support measures are often provided to unviable steel companies, thereby preventing their exit from the market and slowing the industry's needed capacity adjustment.

In addition, an important reason for this stems from the geographical concentration of employment that is so characteristic of the steel industry. Steel companies are often the biggest employers in the local or regional economy where they operate, implying high socio-economic costs for the many steel workers that are laid off and for the communities that rely on the steel plants for their economic livelihood. Plant closures therefore require firm resolve on the part of the companies and governments involved, as well as considerable support to aid those that are hurt the most by the closures, namely, the workers and communities. The challenges are particularly difficult in areas where labour-market rigidities are high, or where lack of growth in other sectors fails to absorb the outflow of steel workers affected by the closures.

A number of other factors also contribute to the slow exit of steel firms from the industry. For example, the durable nature of steel plants and equipment, high environmental cleanup costs, and weak enforcement of environmental regulations can all reduce the speed at which steel firms exit the industry. Broad policies affecting trade and investment, competition, bankruptcy legislation, and financial market regulations also play a key role in determining exit rates across industries including steel. Factors that hinder the exit of inefficient firms from the steel industry contribute to the persistence of excess capacity, and act to depress steel prices and reduce profitability for the entire industry. At the same time, plant exits have a number of economic and social implications for communities, demanding consideration by policymakers of ways to offset these negative social impacts so as to encourage adjustment.

In view of the goal to reduce excess capacity in the steel industry, there is, therefore, a need to understand the nature of exit barriers that prevent capacity adjustments in the steel sector and what policymakers can do to help alleviate them. Some exit barriers are policy-induced, while others are due to the cost structures of steel firms that do not reflect government interventions as such. However, governments can play an important role in facilitating adjustment in the steel industry through measures that promote the flow of labour away from declining steel plants towards higher-growth, higher-income activities.

This paper explores the nature of exit barriers in the steel industry, their social and economic implications, and past policy approaches to deal with exits and steel industry restructuring. By laying out this basic groundwork, the paper develops recommendations on policies to facilitate structural adjustment in the steel sector.

The structure of the paper is as follows. The first section provides an overview of the characteristics of exit in the steel sector. The next section provides a review of the empirical 
and theoretical literature on barriers to exit, both for firms in general and for those in the steel sector. It looks at barriers posited to directly hinder exit as well as factors believed to discourage exit indirectly, such as policies that shield unproductive incumbents from competition and policies to support unproductive plants. The literature review presented in this section of the paper is further substantiated with empirical evidence. The fourth section of the paper examines the social, economic and geographic costs of exits, which are particularly salient for the steel sector and other heavy industries. These include, but are not limited to, earnings lost by displaced workers, possible long-term unemployment, local economy spill-overs, worker reallocation, and health effects for dismissed employees. The fifth section describes past policy approaches to deal with exits, focussing on labour-market policies and providing some examples of adjustment experiences in several economies. The sixth section lists considerations for policymakers and steel firms to encourage the sector's adjustment and develops policy recommendations, and the last section concludes. 


\section{Characteristics of exit in the steel industry}

Among manufacturing industries, steel is an industry with one of the lowest exit rates. In particular, data from the OECD DynEmp 3 database $^{1}$ over the 2000-2015 period show that exit rates in metal products, of which the large majority is steel, are slightly above $5 \%$, meaning that out of 100 units of production, on average, only five exit the market for any given year. The exit rates of the steel industry are quite similar to those in downstream sectors, with machinery and equipment $(4.7 \%)$ having the lowest exit rates in manufacturing. Exit rates in other manufacturing industries are significantly higher.

\section{Figure 1. Average exit rates among manufacturing industries, 2000-2015}

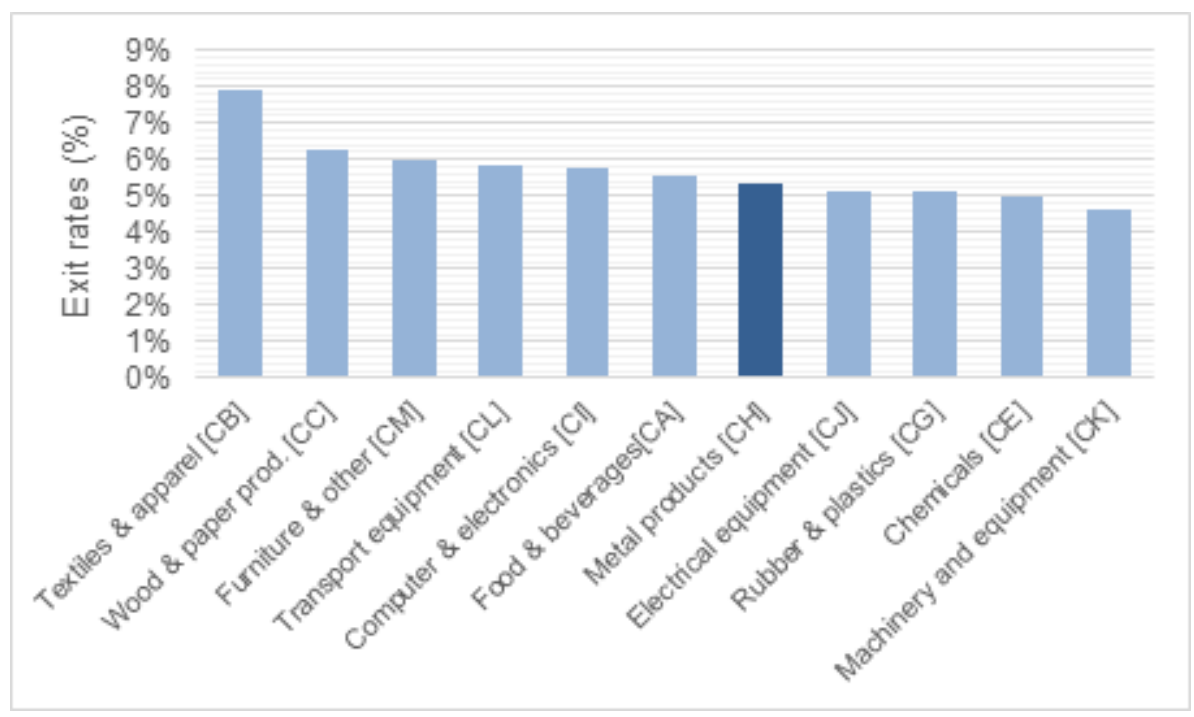

Note: Exit rates are defined as the number of exiting units over the sum of exiting and incumbent units in each industry. The figure reports averages across countries and years, by SNA a38 industries over the period 2000 to 2015 (conditional on the availability of data). The figure focuses on manufacturing industries, excludes selfemployment, as well as the Pharmaceuticals and the Coke and refined petroleum sectors. It refers to the following countries for which DynEmp3 data are available: Austria, Belgium, Brazil, Canada, Costa Rica, Finland, France, Hungary, Italy, Japan, Korea, Portugal, the Netherlands, New Zealand, Norway, Spain, Sweden and Turkey. Owing to methodological differences, figures may deviate from officially published national statistics.

Source: OECD calculations based on the DynEmp3 database, October 2019.

\footnotetext{
${ }^{1}$ The DynEmp project seeks to analyse business and employment dynamics - the entry and growth of successful firms, and the downsizing and exit of the least productive ones. Its associated DynEmp 3 database is based on a distributed data collection to create a harmonised cross-country micro-aggregated database on employment and business dynamics from confidential micro-level data, where the primary sources of firm and establishment data are national business registers and social security data. For more information see: https://www.oecd.org/sti/dynemp.htm.
} 
In general, steel plants tend to remain active for a relatively long time. Plant-level data from James King and from the OECD plant-level database provide more details on the probability of a plant closing after a certain period. Based on information on full plant closures since 1985, Figure 2 shows the gradual increase in the probability of a plant exiting the market over time. After 20 years, the probability of closure for a steelmaking plant approaches $10 \%$, after 40 years it is close to $25 \%$, and after 60 years it rises close to $45 \%$.

Figure 2. Estimates of the probability of plant closure over time

$1985-2019$

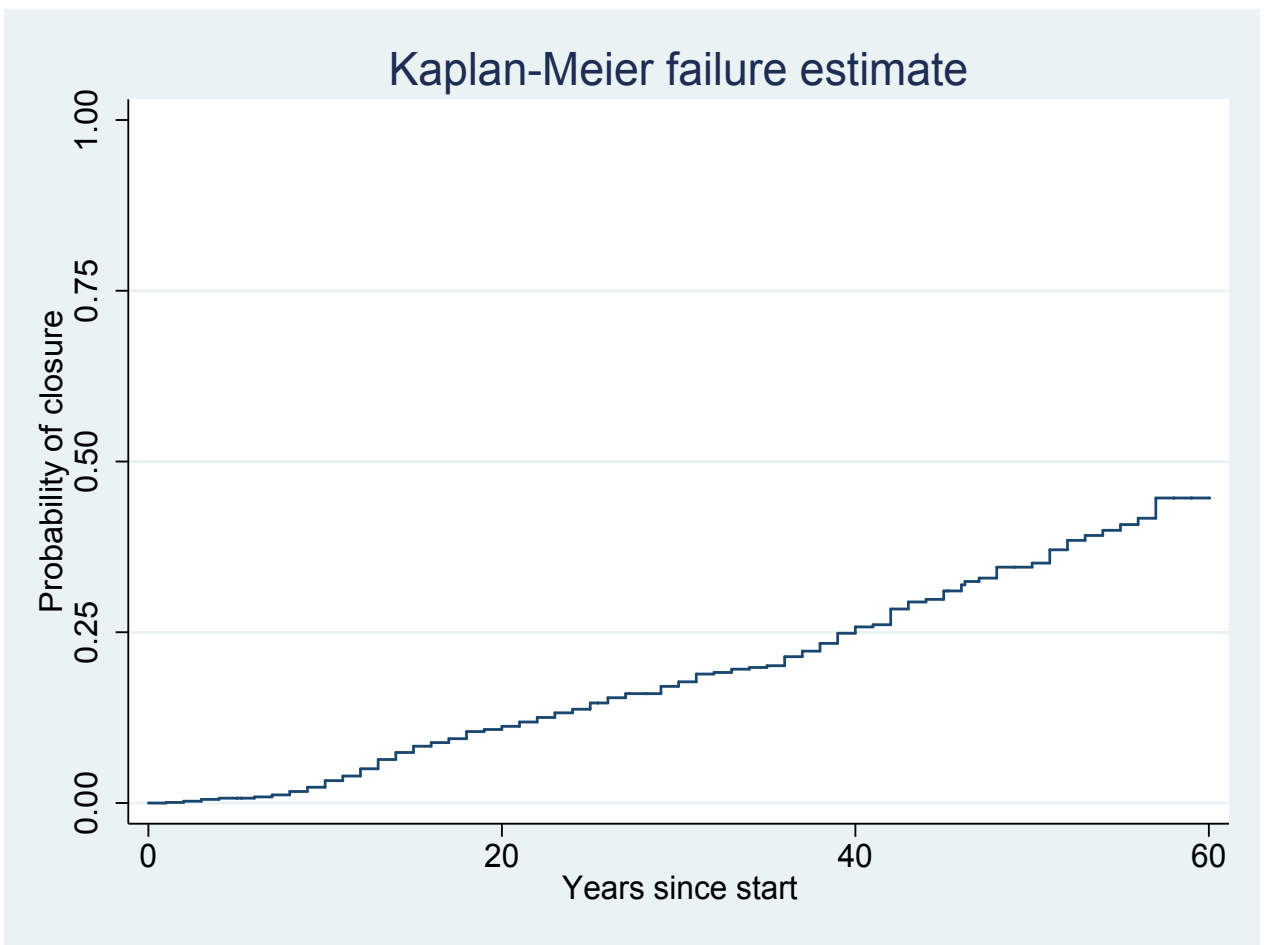

Note: The Kaplan-Meier failure curve estimates the probability of a plant closure over time by computing the number of plants closed over those remaining in operation at each point in time in the sample.

Source: OECD calculations based on James King and OECD plant-level capacity database

However, the rates of exit in the steel industry vary significantly across regions and economies. Based on the sample period since 1985, which was characterised by extensive restructuring in OECD steel economies, the probability of closure of a steelmaking plant after 30 years is found to be significantly higher in the European Union $(25 \%)$ and in the North American Free Trade Agreement (NAFTA) region (24\%) as compared to Africa $(18 \%)$ and Central and South America (11\%) (Figure 3). Similarly, the probability of exit for a plant located in OECD economies after 30 years $(25 \%)$ is higher than that of a plant located in non-OECD economies $(21 \%)$. 
Figure 3. Estimates of the probability of plant closure over time by region

1985-2019

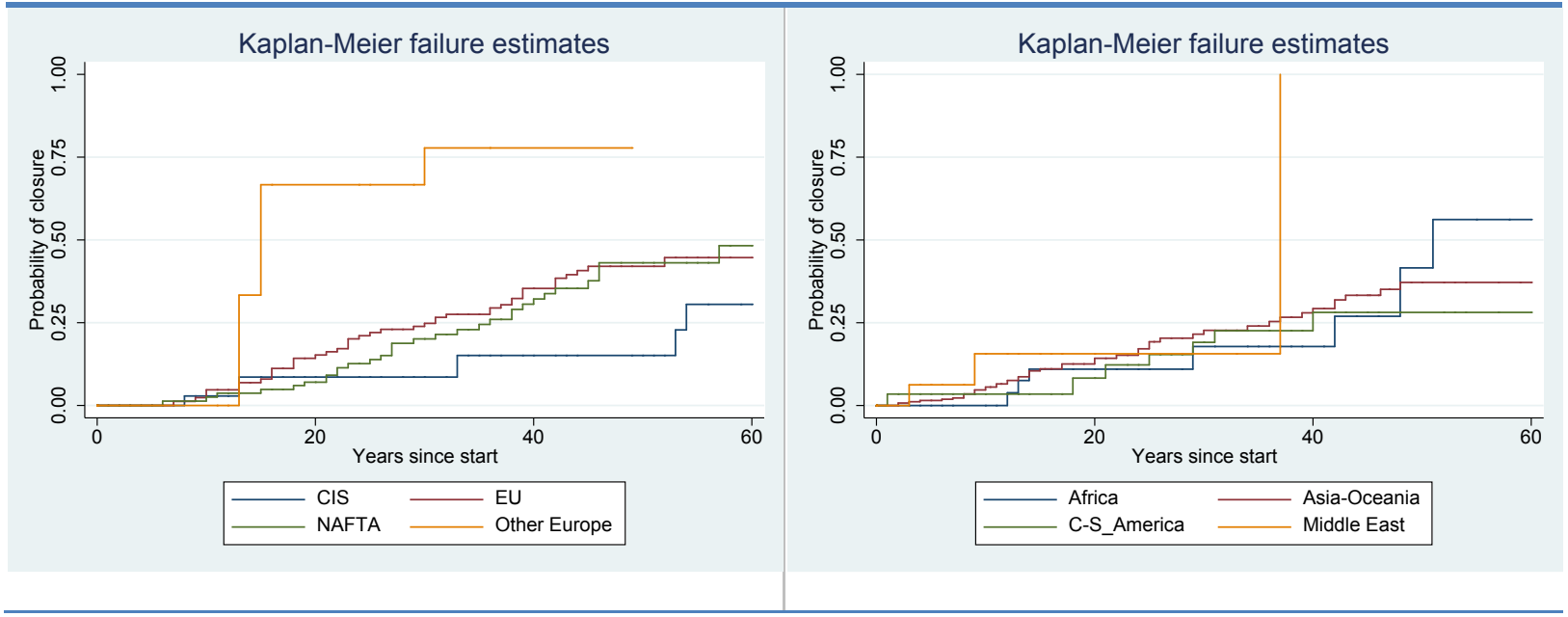

Note: The Kaplan-Meier failure curve estimates the probability of a plant closure over time by computing the number of plants closed over those remaining in operation at each point in time in the sample.

Source: OECD calculations based on James King and OECD plant- level capacity database

Plant characteristics also seem to have an influence on the probability of exiting the market over time. In particular, plants that are part of a multi-plant company as well as larger plants are less likely to exit as time goes by. More specifically, after 30 years the probability of exiting for a plant that is part of a multi-plant company (21\%) is six percentage points lower than that of an isolated plant (27\%) (Figure 4).

Reversely, smaller plants are more likely to exit the market over time. For example, after 30 years the probability that a plant with less than 0.5 million metric tonnes (mmt) of capacity will exit $(48 \%)$ is significantly higher than that of a plant with capacity of $0.5-2$ $\mathrm{mmt}(16 \%)$ and much higher than that of a plant with more than $2 \mathrm{mmt}$ of capacity (1\%). Both observations seem to be associated with the role played by sunk costs as structural exit barriers in the steel sector, which are discussed in detail in section 3.3.1 of the paper. This would suggest that firms are more reluctant to give up on their capital investments the larger they are. 
Figure 4. Estimates of the probability of plant closures by plant characteristics

$1985-2019$

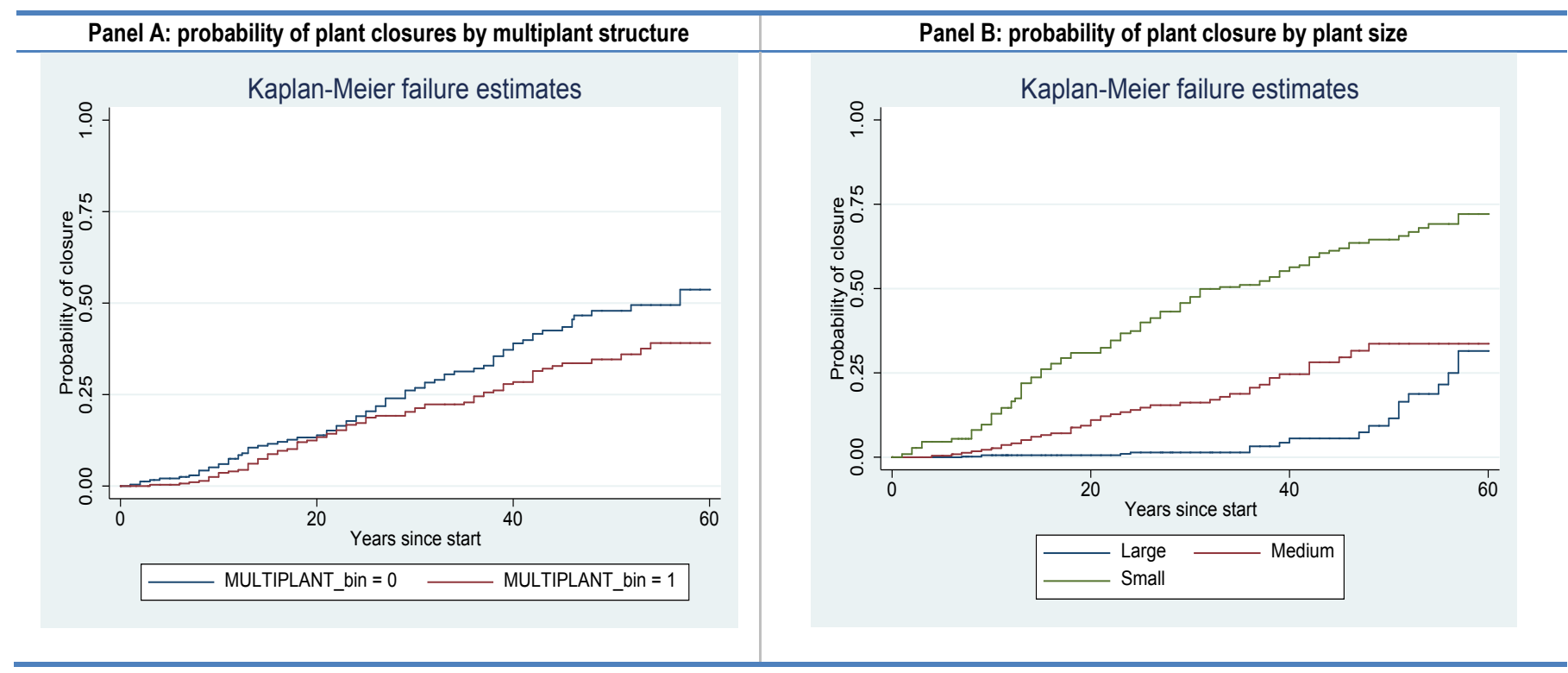

Note: The Kaplan-Meier failure curve estimates the probability of a plant closure over time by computing the number of plants closed over those remaining in operation at each point in time in the sample.

Source: OECD calculations based on James King and OECD plant-level capacity database

The technology choice also bears an influence on the likelihood of a plant exiting over time. In this regard basic-oxygen furnace (BOF) plants are, in general, more likely to exit the market than electric-arc furnace (EAF) plants. A BOF plant has a $36 \%$ probability of exiting after 30 years of service, while an EAF plant as a probability of only $21 \%$ (Figure 5).

However, while these results hold true for OECD economies, where BOF plants are more likely to exit the market than EAF plants (65\% versus $18 \%$ after 30 years), this is not the case for non-OECD economies. In particular, after 30 years the exit probability of an EAF plant $(24 \%)$ is higher than that of a BOF plant $(18 \%)$ in non-OECD economies. This trend is particularly noticeable in the People's Republic of China (hereafter China), where the probability of exit of an EAF plant after 30 years is $44 \%$ compared to $11 \%$ in the case of a BOF plant.

These results may appear at a first glance in contradiction with the observation that closing a BOF plant entails losing greater capital investments than closing an EAF plant (an issue that is further discussed in section 3.3.2 ). There are two possible explanations to this apparent contradiction, which would however require further empirical validation. First, the result may be influenced by the fact that the EAF plants can respond more quickly to demand fluctuations and can be idled during market downturns at reasonable costs without being shut down permanently. Second, it is the case that the examined period (1985-2019) captures a transition in OECD economies from the BOF to the EAF technology. 
Figure 5. Estimates of the probability of plant closure by technology

$1985-2019$

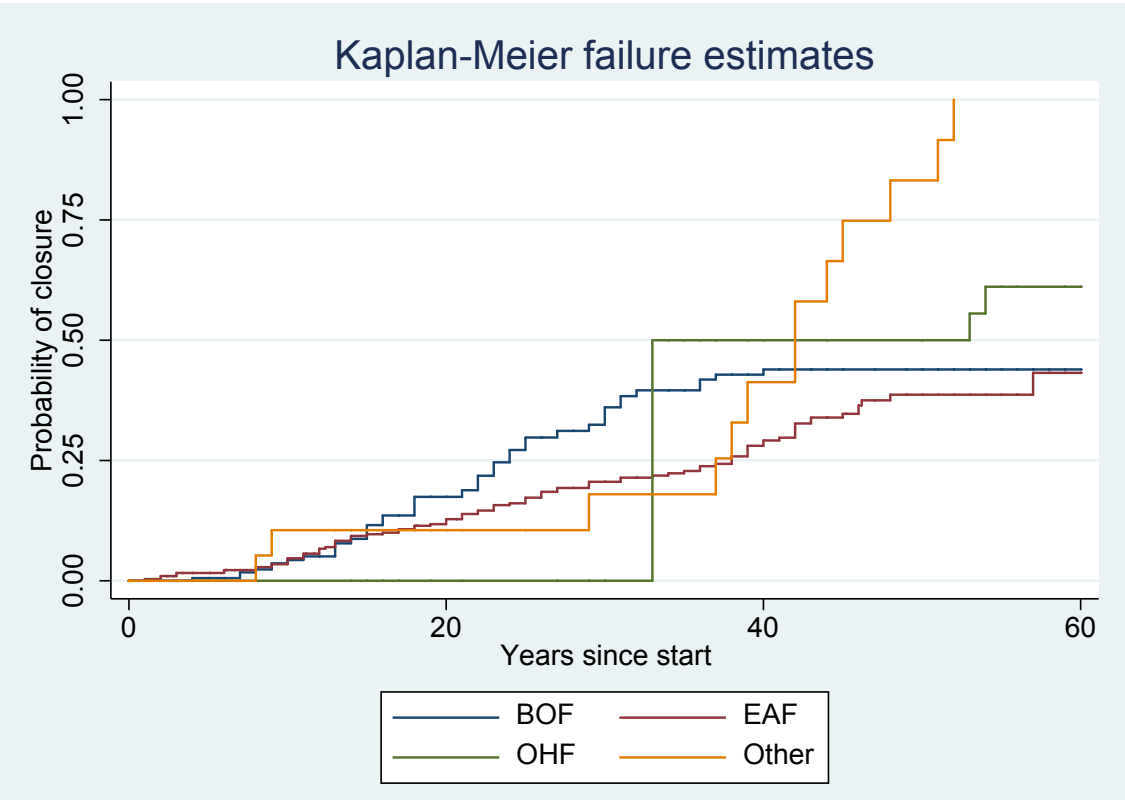

Note: Note: The Kaplan-Meier failure curve estimates the probability of a plant closure over time by computing the number of plants closed over those remaining in operation at each point in time in the sample. Source: OECD calculations based on James King and OECD plant-level capacity database 


\section{Barriers to exit}

Healthy steel markets are characterised by a process of creative destruction, whereby efficient and productive steel firms grow, and unviable steel producers shrink and eventually exit the market. Keeping unviable steel firms in the market, e.g. through government subsidies and other support measures, creates inefficiencies for the industry by maintaining capital and labour resources in facilities that produce steel less efficiently than more productive competitors in the market. ${ }^{2}$

Public support that keeps inefficient plants in the market may act as a major exit barrier. A number of instruments to channel public support to steel firms, which have been used in the past and continue to be used in some economies today, are discussed below in the context of their potential effects on exit. Other policy factors that hinder competition and create barriers to entry (such as capital requirements to commence production, access to finance, FDI rigidities and trade barriers) are also discussed, as they discourage exit indirectly by shielding unproductive incumbents from competition, enabling them to remain in the market. A last category of exit barriers include the capital specificity of steel plants, labour market rigidities and environmental regulations. An extensive theoretical and empirical literature has discussed barriers to exit both for firms in general and for those in the steel sector.

\subsection{Subsidies and other government support measures}

Subsidies and government support measures directed towards the domestic steel industry may have a more distortive impact on the steel sector globally than many structural factors discussed later in this section. Direct and indirect government interventions often differ in frequency and in magnitude across jurisdictions and delay firm exit on the basis of political rather than economic criteria.

Government interventions often lack a transparent and effective framework for the selection of subsidies recipients. Previous evidence has demonstrated that factors like firm size, firm ownership as well as the (political) connections of the firms' management may play a role in the provision of subsidies and government support measures. This hinders fair competition and market efficiency not only within each domestic market but also across jurisdictions. In addition, government support measures may also delay the exit of recipient firms from the market, while more efficient firms exit the market.

Conceptually, the distortive character of subsidies and other government support measures on exit depends on a number of factors: i) the purpose of the government measures and adequacy of rules to enforce this purpose; ii) the transparency of the selection mechanism to choose recipients; iii) the instrument used to channel government support to the selected firm and iv) the extent of follow-through on the use of the subsidy for the selected purpose.

2 This report was written before the Covid-19 pandemic began affecting global steel markets in an unprecedented way. Even the most viable and productive steel firms may struggle in the coming months, as steel market conditions deteriorate dramatically in response to the general economic decline taking place in many countries around the world. In response to the crisis, many government have implemented (macroeconomic policies) to sustain economic activity and the incomes of workers. The challenge will be to phase out the measures and exit from exceptional stimulus once the economy moves out of crisis and begins to recover. 
The framework used will determine the extent of market distortions and the potential to delay firms' exit from the market. In what follows, each of these points is briefly discussed.

Purpose. It is clear that subsidies explicitly provided to avoid ailing firms' closure will, ceteris paribus, delay exit the most. In addition, subsidies for capital investment, when they are not linked to any stringent environmental criteria, are very likely to delay the exit of less efficient firms. Such subsidies may allow inefficient firms to remain profitable at low marginal costs, modernise their equipment and compete with efficient firms that are drawing on their own resources to upgrade their own equipment. Overall less distortive purposes for the provision of direct or indirect government support are, for example, subsidies for investment in research that should have large spill-over effects and benefit all firms, and subsidies to mitigate structurally elevated exit costs and/or compensate workers.

Selection. The selection process of firms benefitting from direct or indirect government interventions should be transparent and open in order to select the most appropriate recipients of government funding. In the case of government procurement for example, a jurisdiction that does not have fair and transparent government procurement rules will most likely artificially inflate the output demand for the few selected steel companies, and thus delay those firms' potential exit.

An appropriate selection of instruments for channeling government measures is also important. For example, non-repayable grants, because they entail a disbursement of cash with no future repayment date, result more easily in a barrier to exit than loans, which need to be repaid in the future and will thus offset future profits. A more detailed discussion on how each instrument type can delay exit for steel firms is provided below.

A complete follow-through of the use of the government support is also very important to avoid that the recipients use the funds to simply boost their current profitability and avoid bankruptcy. For example, when providing a subsidy for environmental purposes to install high quality filters, it will be necessary for the authorities to carefully consider the receipt of the equipment and installation of the filters, and, ideally, to have on-site controls of the equipment. Any failure to enforce that the subsidy be used for its intended purpose will potentially mean that the government support is being directed towards maintaining the company in business, rather than, say, upgrading pollution-reducing devices.

There are a number ways direct and indirect support measures can delay a firm's exit, and those effects are better discussed depending on the instrument used to channel government support.

\subsubsection{Cash grants, cash awards and cost refunds}

Cash grants, awards, cost refunds, are different instruments that allow government funds to be provided to companies, either directly or indirectly. Grants may be tied to assets purchased with the grant, or to a specific project (renovation, transformation, technological upgrading, etc.) but it may also be given to the company without any condition attached. Governments can use awards to distinguish companies that have excelled in a particular domain.

Grants and awards provide additional financial resources to firms, which can be used to cover their fixed or variable costs. Without a specific allocation, such funding can help cushion financial losses occurring during downturns by covering variable costs of any kind, thereby allowing firms to maintain their operations. In the short run, it will be profit maximizing (or loss-minimising) for a firm to continue production as long as (operating) 
revenue covers variable costs, even if it falls short of fixed costs. In cases where grants are tied to asset purchases or specific projects, they can reduce fixed costs or help firms upgrade their production processes, thus inhibiting the exit of inefficient firms (Table 1).

Cost refunds are typically refunds of incurred costs that have already been paid by the company, with the financial transfer taking place upon the company showing proof of payment of these costs. Cost refunds thus have the advantage of theoretically ensuring that funds are used for their predetermined purpose. Moreover, cost refunds often concern only a portion of the disbursed costs, which means that the steel company still participates with some of its own funds in covering the costs incurred. Cost refunds affect exit through the same channels as grants and awards. However, cost refunds are likely to delay exit to a lesser proportion than grants that do not require any disbursement. The larger the refund, the greater the propensity of cost refunds to delay exit.

Table 1. Potential effects of grants, awards and cost refunds on exit

\begin{tabular}{|c|c|c|c|}
\hline $\begin{array}{l}\text { Areas concerned by the } \\
\text { support measure }\end{array}$ & $\begin{array}{l}\text { Impact on cost structure } \\
\text { (variable and fixed costs) }\end{array}$ & $\begin{array}{l}\text { Financial effects relevant for } \\
\text { Exit }\end{array}$ & $\begin{array}{l}\text { Potential economic effects } \\
\text { relevant for Exit }\end{array}$ \\
\hline A. Production & Variable costs & $\begin{array}{l}\text { Firms' operating } \\
\text { revenue }\end{array}$ & Maintain operations \\
\hline B. Company income & Variable costs & $\begin{array}{l}\text { Firms' operating } \\
\text { revenue }\end{array}$ & Maintain operations \\
\hline C. Inputs: Energy, raw materials & Variable costs & $\begin{array}{l}\text { Firms' operating } \\
\text { revenue }\end{array}$ & Maintain operations \\
\hline D. Labour & Variable costs & $\begin{array}{l}\text { Firms' operating } \\
\text { revenue }\end{array}$ & Maintain operations \\
\hline E. Land & Variable costs & $\begin{array}{l}\text { Firms' operating } \\
\text { revenue }\end{array}$ & Maintain operations \\
\hline F. Capital (financial or physical) & Fixed costs & Cost of capital & $\begin{array}{l}\text { Facilitate entry, } \\
\text { upgrade or new } \\
\text { capacity investments }\end{array}$ \\
\hline G. Steel demand & & & \\
\hline
\end{tabular}

Note: A variable cost is a company's cost that is associated with the number of goods or services it produces. A company's variable cost increases and decreases with its production volume. A fixed cost is the other cost incurred by businesses and corporations. Unlike the variable cost, a company's fixed cost does not vary with the volume of production.

Source: OECD elaborations

\subsubsection{Preferential loans, guarantees and other transfers of liabilities}

Governments can provide loans below market rates, either directly or indirectly through a state-controlled bank or other public financial institutions. Debt of the company can also be sold to the government or other public financial institutions in the form of tradable financial market instruments such as bonds or convertible bonds, and is similar to loans. 
The provision of preferential loans can delay exit in two meaningful ways depending on the financial situation of the receiving firm. The effect on exit is greater if the firm receiving these loans is not able to finance its operations unless preferential financing is provided, than when preferential financing only helps the firm reducing its interest payment costs. Moreover, if preferential loans are used to finance investment in new equipment or technical upgrade, they may also lower fixed costs and maintain mills in operation that should otherwise shut down in response to market forces (Table 2).

In comparison with cash grants and awards of the same amount, preferential loans are likely to delay exit by a lesser extent, as they need to be repaid at a given future debt. Hence, although they may certainly be used to boost current profitability numbers and thus delay exit, they will also be a drain on profits at a later stage. Hence, although some ailing firms will simply use the grant or the loan to boost current profitability and pay for current expenditures, their exit should (in theory) only be delayed to some extent.

However, ever-greening of loans, whereby new loans are provided on a rolling basis and the principal is never repaid in full, are likely to delay exit to a greater extent. In the absence of ever-greening, the longer the maturity of a loan and the lower its interest rate, the greater its potential to delay exits, as loss making firms will more easily be able to make the interest payments.

Governments can guarantee the repayment of a company's loan, promising to repay the lender in case the company cannot comply with its obligations. Governments and other public institutions can similarly guarantee companies' bonds. In addition, it is also not uncommon to transfer a company's liability to a state-owned enterprise or bank. Government guarantees can significantly delay firms' exits, as the market perceives firms with an explicit or implicit government guarantee as not being subject to the same market discipline as other firms, and will continue their business relationship with them even when their profitability ratios are low and would indicate an imminent bankruptcy. 
Table 2. Potential effects of preferential loans and guarantees on exit

\begin{tabular}{|c|c|c|c|}
\hline $\begin{array}{l}\text { Areas concerned by the } \\
\text { support measure }\end{array}$ & $\begin{array}{l}\text { Impact on cost structure } \\
\text { (variable and fixed costs) }\end{array}$ & $\begin{array}{c}\text { Financial effects relevant for } \\
\text { Exit }\end{array}$ & $\begin{array}{c}\text { Potential economic } \\
\text { effects relevant for } \\
\text { Exit }\end{array}$ \\
\hline \multicolumn{4}{|l|}{ A. Production } \\
\hline B. Company income & $\begin{array}{l}\text { Fixed costs } \\
\text { (i) interest rate }\end{array}$ & Firms' net profit & Maintain operations \\
\hline \multicolumn{4}{|l|}{ C. Inputs: Energy, raw materials } \\
\hline \multicolumn{4}{|l|}{ D. Labour } \\
\hline \multicolumn{4}{|l|}{ E. Land } \\
\hline F. Capital (financial or physical) & Fixed costs & $\begin{array}{l}\text { Cost of capital } \\
\text { Firms' solvency }\end{array}$ & $\begin{array}{l}\text { Facilitate } \\
\text { entry, } \\
\text { upgrade or } \\
\text { new capacity } \\
\text { investments } \\
\text { Maintain } \\
\text { operations }\end{array}$ \\
\hline G. Steel demand & & & \\
\hline
\end{tabular}

Note: A variable cost is a company's cost that is associated with the number of goods or services it produces. A company's variable cost increases and decreases with its production volume. A fixed cost is the other cost incurred by businesses and corporations. Unlike the variable cost, a company's fixed cost does not vary with the volume of production.

Source: OECD elaborations

\subsubsection{Equity infusion and conversions}

Governments sometimes provide cash injections or debt relief in exchange for equity. In equity infusions, new company shares are created and sold to the government. In conversions, such as debt-for-equity swaps, debt contracted by the company towards the government is transformed into equity shares. In the large majority of those cases, the equity infusion or debt conversion is very beneficial to the steel firms, as it improves the firm's debt position of the firm and as such may delay its exit.

Similarly, governments can forego revenues by writing-off a fraction or the totality of a loan they had provided to a steel company, or by restructuring a company's debt in a way that advantages the borrower (e.g. extending maturity while keeping the same rate of interest). These instruments are often used with the clear purpose to avoid exit.

When governments write off and restructure a firm's debt, or infuse equity into the firms, they directly reduce its fixed costs by lowering the overall amount of liabilities and reduce the amount of interest rates payment incurred by a company each year. The two effects help firms maintain operations by improving their financial performance. This in turn help firms 
to weather market downturns, which would otherwise lead them to either close plants or exit the market (Table 3).

It should also be noted that these are often the preferred instruments to channel government support to new steel capacity investment projects (OECD, 2015 $\left.5_{[1]}\right)$.

Table 3. Potential effects of equity infusions, conversions and debt forgiveness on exit

\begin{tabular}{|c|c|c|c|}
\hline $\begin{array}{l}\text { Areas concerned by the } \\
\text { support measure }\end{array}$ & $\begin{array}{l}\text { Impact on cost structure } \\
\text { (variable and fixed } \\
\text { costs) }\end{array}$ & $\begin{array}{l}\text { Financial effects } \\
\text { relevant for Exit }\end{array}$ & $\begin{array}{l}\text { Potential economic } \\
\text { effects relevant for Exit }\end{array}$ \\
\hline \multicolumn{4}{|l|}{ A. Production } \\
\hline B. Company income & $\begin{array}{l}\text { Fixed costs } \\
\text { (i) interest rate }\end{array}$ & Firms' net profit & Maintain operations \\
\hline \multicolumn{4}{|l|}{$\begin{array}{l}\text { C. Inputs: Energy, raw } \\
\text { materials }\end{array}$} \\
\hline \multicolumn{4}{|l|}{ D. Labour } \\
\hline \multicolumn{4}{|l|}{ E. Land } \\
\hline $\begin{array}{l}\text { F. Capital (financial or } \\
\text { physical) }\end{array}$ & Fixed costs & Firms' liabilities & $\int_{\text {Firms' solvency }}^{\text {Maintain operations }}$ \\
\hline G. Steel demand & & & \\
\hline
\end{tabular}

Note: A variable cost is a company's cost that is associated with the number of goods or services it produces. A company's variable cost increases and decreases with its production volume. A fixed cost is the other cost incurred by businesses and corporations. Unlike the variable cost, a company's fixed cost does not vary with the volume of production.

Source: OECD elaborations

\subsubsection{Tax benefits}

Other forms of targeted government support are tax exemptions, reductions, and credits, when directed specifically at the steel industry or at specific steel firms. Tax benefits can be given in the form of tax credits, tied to the purchase of some equipment (produced domestically or not), to the completion of a project, or even given to the steel firm as a reward for a specific contribution. Tax benefits can be on inputs (e.g. reduced tax for fuel) or on outputs (e.g. reduced VAT, reduced sale tax). Moreover, rebates can also be provided at the level of the corporate income tax, of the property tax of the factories, on export tariffs and on the firm's contribution to workers' social security scheme, etc.

By reducing the costs of doing business for steel firms in specific jurisdictions or for specific steel firms, tax benefits selectively alleviate steel firms' burden and thus may reduce exit. Depending on the stated purpose, tax exemptions, reductions and credits can affect firms' performance and exit in multiple ways (Table 4). The main channel by which tax benefits are likely to delay exit is the reduction of variable costs, which in turn support firms' operating revenue and allow them to maintain operations. When tax credits are given to equipment purchases, they may lower fixed costs and incentivise plant upgrade or new investment, which may, on the one hand help firms remaining in the market and, on the other hand, facilitate exit of older plants. 
Table 4. Potential effects of tax benefits on exit

\begin{tabular}{|c|c|c|c|}
\hline $\begin{array}{l}\text { Areas concerned by the } \\
\text { support measure }\end{array}$ & $\begin{array}{l}\text { Impact on cost structure } \\
\text { (variable and fixed costs) }\end{array}$ & $\begin{array}{c}\text { Financial effects relevant for } \\
\text { Exit }\end{array}$ & $\begin{array}{l}\text { Potential economic effects } \\
\text { relevant for Exit }\end{array}$ \\
\hline A. Production & Variable costs & $\begin{array}{l}\text { Firms' operating } \\
\text { revenue }\end{array}$ & Maintain operations \\
\hline B. Company income & Variable costs & $\begin{array}{l}\text { Firms' operating } \\
\text { revenue }\end{array}$ & Maintain operations \\
\hline $\begin{array}{l}\text { C. Inputs: Energy, raw } \\
\text { materials }\end{array}$ & Variable costs & $\begin{array}{l}\text { Firms' operating } \\
\text { revenue }\end{array}$ & Maintain operations \\
\hline D. Labour & Variable costs & $\begin{array}{l}\text { Firms' operating } \\
\text { revenue }\end{array}$ & Maintain operations \\
\hline E. Land & Variable costs & $\begin{array}{l}\text { Firms' operating } \\
\text { revenue }\end{array}$ & Maintain operations \\
\hline F. Capital (financial or physical) & Fixed costs & Cost of capital & $\begin{array}{l}\text { Facilitate entry or } \\
\text { new capacity } \\
\text { investments, } \\
\text { facilitate closures }\end{array}$ \\
\hline G. Steel demand & Revenues & $\begin{array}{l}\text { Firms' operating } \\
\text { revenue }\end{array}$ & Maintain operations \\
\hline
\end{tabular}

\subsubsection{Government approach to mergers and acquisitions}

Governments usually take into consideration a host of different policy objectives when facilitating mergers and acquisitions. This potentially makes the terms of governmentsteered mergers and acquisition different from those that private individual profit-seeking companies would have sought. In many cases government mandated mergers are not economically driven, but aimed at creating large domestic "champions" from firms that may have exited the market or be subject to stricter domestic competition absent government intervention.

\subsubsection{Input support}

Steel is produced in many grades and qualities, requiring various raw materials to produce crude steel and a number of alloying materials to enhance the properties of the steel. The markets for these raw materials are global in nature, and few economies, if any, have domestic supplies of all the inputs needed for steel production. Even countries that are major extractors of steelmaking materials typically import some of the very same commodities, because of different material qualities, cost factors and/or the locations of the steel mills and mining operations. In the case of iron ore and coking coal, a major share of the mined output is traded internationally.

Over the past decade, governments have often implemented measures to restrict exports of steelmaking raw materials. These measures can take a variety of forms, including export licensing requirements that limit who can export and how much can be traded. Export taxes have also been widely used in past years while export prohibitions and quotas are used more rarely reflecting the fact that such measures would generally be inconsistent with 
international rules on trade. These export restrictions distort markets for internationally traded raw materials as supply is redirected to the domestic market, lowering domestic prices relative to international prices. Steel production costs in economies is dependent on imported raw materials thus increase relative to those in raw material exporting countries applying restrictions. At the same time, when domestic prices of raw materials are lower than they would otherwise be due to export restrictions, upstream mining activity can become less profitable, thus potentially hindering investment and innovation in those sectors. Moreover, export restrictions of raw materials can have particularly distortive effects when used in combination with export support and incentives on downstream products, such as export duty or tax rebate incentives.

In addition to raw materials, governments can provide other input support to steel producers, including utilities, land and infrastructure support. For example, governments can set artificially low prices for utilities such as electricity, water and road services that it provides to a steel company through its public services. Governments have also provided land for steel plants at a lower than market price and reductions or exemptions in land-use fees, as well as services and infrastructure through government agencies or state-owned enterprises that benefit steel producers by lower their input costs.

Input support as described above helps reducing the costs of producing steel. During downturns in the steel market, when steel prices are falling and reaching low levels, steel firms will continue to operate as long as they meet their variable costs of production. When inefficient firms are unable to cover their variable costs, under normal market conditions they would be forced to shut down. Raw materials comprise a significant portion of steelmakers' total costs (along with fuel, power costs and utilities), and their low availability and relatively high prices in recent years should have yielded greater exit of inefficient steel producers from the market. Export restrictions and other input support that artificially lower variable costs can thus reduce the probability of inefficient steel producers exiting the market during periods of steel market weakness when steel prices fall to relatively low levels (Table 5). 
Table 5. Potential effects of input support on exit

\begin{tabular}{|c|c|c|c|}
\hline $\begin{array}{l}\text { Areas concerned by } \\
\text { the support measure }\end{array}$ & $\begin{array}{l}\text { Impact on cost } \\
\text { structure (variable } \\
\text { and fixed costs) }\end{array}$ & $\begin{array}{l}\text { Financial effects } \\
\text { relevant for Exit }\end{array}$ & $\begin{array}{l}\text { Potential economic } \\
\text { effects relevant for } \\
\text { Exit }\end{array}$ \\
\hline A. Production & Variable costs & $\begin{array}{l}\text { Firms' operating } \\
\text { revenue }\end{array}$ & Maintain operations \\
\hline \multicolumn{4}{|l|}{ B. Company income } \\
\hline $\begin{array}{l}\text { C. Inputs: Energy, raw } \\
\text { materials }\end{array}$ & Variable costs & $\begin{array}{l}\text { Firms' operating } \\
\text { revenue }\end{array}$ & Maintain operations \\
\hline D. Labour & Variable costs & $\begin{array}{l}\text { Firms' operating } \\
\text { revenue }\end{array}$ & Maintain operations \\
\hline E. Land & $\begin{array}{l}\text { Fixed and variable } \\
\text { costs }\end{array}$ & $\begin{array}{l}\text { Cost of capital } \\
\text { Firms' operating } \\
\text { revenue }\end{array}$ & $\begin{array}{l}\text { Facilitate entry or new } \\
\text { capacity investments }\end{array}$ \\
\hline \multicolumn{4}{|l|}{$\begin{array}{l}\text { F. Capital (financial or } \\
\text { physical) }\end{array}$} \\
\hline G. Steel demand & & & \\
\hline
\end{tabular}

Note: A variable cost is a company's cost that is associated with the number of goods or services it produces. A company's variable cost increases and decreases with its production volume. A fixed cost is the other cost incurred by businesses and corporations. Unlike the variable cost, a company's fixed cost does not vary with the volume of production.

Source: OECD elaborations

\subsubsection{Output support}

Government support can also be targeted the steel firm's output. Tariffs on foreign imports and local content support to consumers or downstream industries are types of measures that have the potential to create higher domestic prices and a higher demand for a steel firm's products. Subsidies can be provided based on export performance (export subsidies), tariffs can be placed on imports in order to create price support for a domestic firm's output (tariffs on imports), subsidies can be given to downstream industries on the condition that they use domestic steel (local content support to consumers or downstream industries), or the government can directly buy from local producers.

Export subsidies are monetary amounts provided by the government to the steel firm based on the firm's export performance. This form of subsidy is rare, as it is explicitly forbidden in WTO rules.

Tariffs on imports increase steel import purchase prices and thus increase the relative price of domestic steel within the domestic economy, which can help domestic companies to delay their exit. Sometimes tariffs are used as remedies in response to foreign subsidies, in which case they are only intended to compensate for the impact of foreign subsidisation on the imported products. 
Similarly, quotas on imports provide price and quantity support to domestic steel firms, by restricting the supply of a given steel product in the domestic economy. These instruments are also monitored by the WTO.

Local content requirements applied to consumer or downstream industries increase the demand for domestic steel and thus constitute another form of support to domestic steel producers. Similarly, local content requirements in government procurement include discretionary preferences based on a company's geographical location rather than features of the company's goods. This also constitutes a form of support to certain steel companies based on their location, as local steel-using companies will tend to obtain more of their steel inputs locally instead of from international markets.

The above-mentioned forms of output support are likely to delay exit through the demand side by boosting revenues. More sales are likely to improve steelmakers' profitability and cushion their losses during market downturns thereby discouraging exit (Table 6).

\section{Table 6. Potential effects of various forms of output support on exit}

\begin{tabular}{l|l|l|l}
\hline $\begin{array}{l}\text { Areas concerned by } \\
\text { the support measure }\end{array}$ & $\begin{array}{l}\text { Impact on cost } \\
\text { structure (variable } \\
\text { and fixed costs) }\end{array}$ & $\begin{array}{l}\text { Financial effects } \\
\text { relevant for Exit }\end{array}$ & $\begin{array}{l}\text { Potential economic } \\
\text { effects relevant for } \\
\text { Exit }\end{array}$ \\
\hline A. Production & Revenues & Firms' profitability & Maintain operations \\
\hline $\begin{array}{l}\text { B. Company income } \\
\text { C. Inputs: Energy, raw } \\
\text { materials }\end{array}$ & & & \\
\hline $\begin{array}{l}\text { D. Labour } \\
\text { E. Land }\end{array}$ & & & \\
\hline $\begin{array}{l}\text { F. Capital (financial or } \\
\text { physical) }\end{array}$ & Firms' profitability & \\
\hline \begin{tabular}{l} 
G. Steel demand \\
\hline
\end{tabular} & & & Maintain operations \\
\hline
\end{tabular}

Note: A variable cost is a company's cost that is associated with the number of goods or services it produces. A company's variable cost increases and decreases with its production volume. A fixed cost is the other cost incurred by businesses and corporations. Unlike the variable cost, a company's fixed cost does not vary with the volume of production.

Source: OECD elaborations

\subsection{Factors that reduce competition}

Another factor which indirectly influences exit is the degree of competition within a market. Greater competition incentivises successful incumbents to adopt emerging technology and improve efficiency while at the same time results in the loss of market share and exit of unsuccessful firms. In addition, factors which inhibit entry can prevent potential entrants from making crucial investments necessary to reach their minimum efficient scale 
(MES). ${ }^{3}$ These factors may also discourage inefficient firms from exiting, as they enable current firms that are not producing at the MES to continue their inefficient operations and avoid exiting. Such barriers may include constraints on inward foreign direct investment (FDI) and trade, limitations on access to finance and policies which directly or indirectly support the performance of incumbents, all of which may result in unintended policy outcomes. In both cases, entry by domestic and/or foreign firms is reduced and, in the absence of market-based competition pressures, less efficient facilities are able to avoid closure.

\subsubsection{Capital requirements and access to finance}

While barriers to entry stem from numerous sources, one that is highly relevant to the steel industry is the enormous capital cost involved in setting up and adding capacity to a steel factory. A large steel mill complete with multiple furnaces and rolling mill can easily cost the equivalent of billions of U.S. dollars, resulting in considerable sunk costs at the time of entry. Individual production units can cost hundreds of millions of dollars, with some estimated average investment costs calculated as follows: an EAF (USD 154 million), a slab caster (USD 154 million), a hot roll mill (USD 506 million), a welded tube and pipe mill (USD 120 million), a bar rolling mill (USD 88 million), and a heavy section and rail mill (USD 485 million) (Steel on the net, 2018 ${ }_{[2]}$ ). Investment costs can vary significantly across countries and plants, however. For example, the aforementioned source notes that capital costs for a fully integrated slab plant with continuous casting can vary by several billion U.S. dollars across the plants in its sample, and wide variations are also observed for other types of production units.

Steel is a very capital-intensive industry that generates considerable economies of scale. As a result, the steel industry is more likely to encourage entry by larger firms - with potentially lower average costs of production which, in turn, will help induce exit and consolidation of less efficient and smaller facilities. Tang and Zannetos $\left(1986_{[3]}\right)$ find that plants with lower production capacity and smaller blast furnaces were more likely to exit during 1970-1982. Deily $\left(1991_{[4]}\right)$, who studies plant exit by integrated steel firms during 1977-1987, also found that smaller plants were more likely to shut down. Blonigen, Liebman and Wilson $\left(2013_{[5]}\right)$ showed that smaller steel production lines inside U.S. steel plants were more likely to shut down during 1978-2007. Indeed, preliminary analysis of the characteristics of exit in the steel sector presented in section 2 confirm that smaller plants are more likely to shut down during the 1985-2018 period.

Because of the high capital intensity of the steel industry, factors that prevent potential entrants from engaging in large-scale investments undermine their ability to reduce their average costs to competitive levels. Limited access to finance can therefore serve as a barrier to entry. Financial constraints for potential entrants results in weaker competitive pressure for incumbents and ultimately lead to less efficient firms and plants remaining in operation. There are a number of papers which demonstrate that access to finance is important for firm entry, subsequent growth of entrants and exit - see (Carreira and Silva, $\left.2010_{[6]}\right)$ for a review of the empirical literature on financial constraints and firm entry, growth and exit.

For example, Aghion et al., $\left(2007_{[7]}\right)$ finds that the development of financial institutions can enhance the growth of new firms after entering the market. Similarly Bravo-Biosca,

\footnotetext{
${ }^{3}$ The minimum efficient scale is the level of output at which the average cost of production is minimised.
} 
Criscuolo and Menon $\left(2013_{[8]}\right)$ provide an overview of the literature and data that suggests that lack of access to finance is a considerable barrier to business dynamism and growth. However, recent work by Aghion et al., $\left(2018_{[9]}\right)$ finds that access to finance results in counteracting effects on entry and exit. On the one hand, enhanced financial availability enables successful firms to innovate, invest and grow. However, better access to finance can disincentivise the entry of new firms by allowing inefficient incumbents to survive in the market. Thus, if finance availability is targeted towards low-productivity incumbents rather than innovative entrants, this can discourage entry and competition within the market, thereby reducing exits.

The difficulty of addressing these issues is particularly heightened given the information asymmetries in the market for finance and the potential for unintended non-market distortions. Ensuring a healthy banking system is therefore important for the exit of inefficient firms. For example, weakness in the banking sector may lead to the prevalence of zombie firms, thereby discouraging exit. A recent study by Andrews, McGowan and Valentine $\left(2017_{[10]}\right)$ finds that zombie firms are more likely to be connected to weak banks, implying that zombie congestion is somewhat driven by bank forbearance.

\subsubsection{Restrictions on FDI}

Restrictions on FDI can hinder competition and thus discourage exit for a number of reasons. First, FDI rigidities discourage the entry of foreign firms into a host market, hence reducing the competition faced by domestic players. This is particularly relevant since most FDI is undertaken by multinational firms who tend to be more productive than domestic businesses (Helpman, Melitz and Yeaple, 2004 $\left.{ }_{[11]}\right)$. The presence of foreign competition may force less productive domestic firms out of the market particularly when foreign firms are competing with domestic ones - see e.g. Harrison, Martin and Nataraj $\left(2011_{[12]}\right)$ for India, De Backer and Sleuwaegen, $\left(2003_{[13]}\right)$ for Belgium, Franco and Weche Gelübcke $\left(2015_{[14]}\right)$ for Germany, or Kokko and Thang $\left(2014_{[15]}\right)$ for Viet Nam.

Second, greater competition may encourage highly productive domestic firms to invest in new technologies thereby further enhancing performance (OECD, 2015 $\left.{ }_{[16]}\right)$. Thus enhanced competition from inward FDI may lead to enhanced business dynamism and facilitate the reallocation of resources from the least productive to more productive firms. ${ }^{4}$ Studies that examine both developed and emerging markets (examining the economy as a whole) find that inward FDI results in market share reallocation, from inefficient to efficient firms (Harrison, Martin and Nataraj, 2011 [12]; Bloom, Schankerman and Van Reenen, 2013 ${ }_{[17]}$; Fons-Rosen et al., 2013 $\left.3_{[18]}\right)$.

\subsubsection{Trade restrictions}

Trade restrictions are sometimes perceived as representing another barrier to entry and competition, which may thus discourage plant exit. Trade restrictions on steel restrict (foreign) supplies, making it easier for domestic steel producers to compete. They can also lead to higher steel prices, improved profits and higher employment and wages for domestic producers. But at the same time, such restrictions impact other segments of the economy through higher input costs to users of the materials being affected by trade restrictions.

\footnotetext{
${ }^{4}$ At the same time, FDI may result in a number of positive productivity externalities to domestic firms through a variety of channels, which can lead to productivity gains for some firms and the exit of others (see Santos (2017[159]) for a review on the literature of FDI externalities).
} 
A number of theoretical models indeed suggest that trade barriers may provide protection to inefficient incumbents resulting in lower rates of exit, less resource allocation and lower productivity growth (Pavcnik, 2002 $2_{[19]}$; Melitz, 2003 ${ }_{[20]}$; Bernard et al., 2007 ${ }_{[21]}$ ). Conversely, the removal of entry barriers (such as trade restrictions) are thought to increase competition within the market, shifting market share to more productive plants, shrinking the market share of inefficient incumbents and forcing some of the latter to exit (Syverson, $\left.2011_{[22]}\right)$.

In terms of steel plants, Deily $\left(1987_{[23]}\right)$ notes that trade protection may serve as an exit barrier, especially in the long run as it reduces the incentives to innovate and upgrade existing plants and tests this empirically using data on the U.S. steel industry. The results suggest that the Reagan-negotiated quotas during the 1980s were negatively associated with investment, suggesting that despite the higher prices caused by the binding quotas, firms were more focused on a predicted decline in future profits rather than making adjustments to improve efficiency.

However, more recent findings seem to be less conclusive. Blonigen, Liebman and Wilson $\left(2013_{[24]}\right)$ investigated the exit behaviour of individual production lines inside U.S. steel plants and did not find empirical evidence that antidumping measures decrease the likelihood of exit of steel production lines in the U.S. Instead, they find that production lines are more likely to avoid exit if they are newer, larger, modernised, and are operated by mini-mill producers.

While the theoretical models just presented suggest the presence of a negative association between trade restrictions and exit, empirical findings are thus less conclusive. As such, further research is needed to gain better policy insights specifically on the relationship between trade restrictions and the propensity for weak firms that benefit from the restrictions to exit the market. In addition, when looking at trade protection and exit, one should also take into account global effects and not solely the partial (economy-specific) effects on exit. Thus, while protection used to offset foreign subsidisation could theoretically slow exit in the domestic market, it could potentially counteract the delay in the exit of potentially inefficient firms that remain in the market thanks to subsidies and government support measures they receive.

\subsubsection{Direct and indirect government interventions}

Government policies can create exit barriers or exacerbating exit barriers that stem from structural (industry) barriers as discussed above. For example, the economic and social implications of exits are particularly salient for the steel sector, where substantial job losses, earnings reduction, worker and firm reallocation, and other adjustment challenges tend to be concentrated in time and geography. Specific government measures may alleviate the social costs associated with plant closures but at the same time become barriers to exit. The costs to workers of dismissal are socially undesirable, and make it difficult to carry out plant closures, but this can become a more prominent barrier to exit and increase the eventual costs of adjustment when addressed by government policies that impede or restrict the efficient functioning of labour markets, for example.

Looking more broadly, the regulatory framework may also include indirect features that are not conducive to exit. Previous OECD work has focussed on policy reforms to encourage the restructuring and exit of weak firms in order to boost overall productivity across economies. Firms that would typically exit or restructure in a competitive market, i.e. so-called "zombie" firms, tend to depress productivity growth, as they divert resources 
from flowing to more productive and successful firms and slow the diffusion of best practices and new technologies across economies (Adalet McGowan, Andrews and Millot, $2017_{[25]}$

Much of the problem stems from weaknesses in the banking system and insolvency regimes. For example, bankruptcy regulation might play an important role (Adalet McGowan, Andrews and Millot, 2017 [26]). Dysfunctional insolvency systems induce creditors to keep their ailing borrowers in operation rather than force bankruptcy proceedings, in order to save the values of their credits (McGowan, Andrews and Millot, $2017_{[27]}$ ). Failure to enforce solvency requirements on heavily indebted steel companies further postpones the exit of inefficient firms and results in considerable misallocation of resources. As another example, the lax enforcement of accounting, fiscal, environmental, labour market and other standards and regulations may alleviate budget and other constraints, thus postponing the exit of inefficient plants.

Cross-country policy indicators developed by the OECD highlight several features of insolvency regimes that potentially impose barriers to restructuring. These include creditors' inability to initiate restructuring, an indefinite stay on assets (a stay on assets stops actions by creditors to collect debts from a debtor), no "cram-down" of restructuring plans on dissenting creditors (i.e. to override the votes of a minority of creditors who vote against the restructuring plan), and the dismissal of incumbent management during restructuring (which can increase private incentives of management to hide the true financial state of the firm). Addressing such barriers can help promote restructuring of ailing firms and encourage exit.

\subsection{Cost considerations}

\subsubsection{Steel specific capital and sunk costs}

Sunk costs, according to Tirole $\left(1988_{[28]}\right)$, are "investment costs that produce a stream of benefits over a long horizon but can never be recouped." Sunk costs cannot be recovered if a company decides to leave an industry because the invested capital is specific to an industry and has little or no resale value. Unlike fixed costs, which are often financed along the way and terminated if the firm exits, sunk costs frequently involve a lump sum payment that must often be paid before entry. Furthermore, even if equipment is amortised over ten or more years, the firm is still responsible for any remaining payments if the factory shuts down.

Rosenbaum and Lamort (1992 $\left.{ }_{[29]}\right)$ explain that since the sale of non-recoverable assets (sunk costs) cannot be included in the stream of payments provided by these assets, then a longer period of production is needed to recover a sufficient return of their investment. This helps explain why firms with greater sunk costs remain in operation longer than firms with assets that have greater resale value (i.e. recoverable capital costs), which is particularly relevant to steel plants.

Indeed, steel capital has relatively limited value for the production of goods other than steel. For example, investments in steelmaking equipment and the relining of blast furnaces have low liquidation values or high costs of transfer or conversion. In fact, the costs associated with the dismantling and removal of this equipment implies that steel capital may have negative value in the advent of exit. The relatively limited alternative uses for steel capital 
provides an incentive for firms to continue to operate and thus acts as an exit barrier in the steel industry.

The incentive to extend the operation of industry-specific capital in order to recoup otherwise non-recoverable investment costs is particularly large in the steel industry due to the durability of steel capital. As Deily $\left(1987_{[23]}\right)$ notes, steel capital frequently lasts more than 20 years. Thus, while the specialised nature of steel capital induces owners to delay exit, the durability of steel capital makes this delay financially viable while operating losses are sufficiently small.

It is important to point out that sunk costs (such as industry-specific capital) and the durability of steel capital also serve as a barrier to entry (Rosenbaum and Lamort (1992 [29]), Eaton and Lipsey $\left(1980_{[30]}\right)$. The added risk of sunk costs makes them an even greater barrier to entry than fixed costs (Pindyck, 2008 $8_{[31]}$ ). By inhibiting entry, these key aspects of steel capital (industry specificity and durability) undermine exit indirectly, as more efficient firms are prevented from entering and allowing less efficient facilities to continue operating. In sum, both the steel-specific nature and durability of steel capital serve as barriers to exit and entry.

\subsubsection{Demand expectations and cyclicality}

The academic literature on firm behaviour suggests that the cyclical nature of the market can also influence investment and exit decisions. The cyclical nature and uncertainty around demand in the steel industry works as an additional exit barrier, since firms have an incentive to delay the retirement of any facilities that may suddenly become useful during the next economic uptick. Lambson $\left(1991_{[32]}\right)$ highlights the importance of market uncertainty in sunk-cost investments within a theoretical framework. If demand conditions are expected to remain favourable for a substantial period of time, firms are more likely to construct plants entailing higher sunk costs but lower operating costs. In contrast, if demand conditions are expected to be transitory, firms are more likely to build plants with low sunk costs but high operating costs.

This rationale is highly relevant to the steel industry, where production relies on two main technologies: a high sunk cost technology (BOF production) and a (relatively) lower sunk cost technology (EAF production). ${ }^{5}$ Moreover, BOFs can have lower operating costs compared to EAFs, depending on the prices of the key steelmaking raw materials, namely, iron ore, coking coal, and ferrous scrap. Steel consultant James King estimates the cost of a tonne of BOF liquid steel in 2018 to be USD 328, compared to an estimated USD 430 per tonne for EAF steel (Steel on the net, 2019[33]). ${ }^{6}$ Nevertheless, BOF and EAF production costs within and across markets can vary significantly, based on several factors beyond raw material cost.

\footnotetext{
${ }^{5}$ Investment costs for BOF factories average cost USD 1100 per metric tonne of capacity, while investment costs for EAFs are under USD 300. See https://blog.steel-technology.com/basic-oxygen-furnace-steelmaking/

${ }^{6}$ The BOF estimate is for a typical size integrated BOF plant, 3 million tonnes per annum (Mtpa), at a Japanese coastal site with its own coke and sinter plant, using imported ore and coal purchased at international prices with third party transport, and is assumed to make commodity grade carbon steel for flat products with average labour productivity. The EAF estimate is for a typical size plant of about 1 Mtpa capacity, based in Japan, using a 100\% scrap charge to EAF (no DRI or iron ores), and producing commodity grade carbon steel for long products with average labour productivity. See https://www.steelonthenet.com/cost-bof.html and https://www.steelonthenet.com/costeaf.html.
} 
If BOF production entails greater sunk costs but lower operating costs, it would then be rational to invest in BOF capital during periods of stronger and more stable demand. This may be one factor helping to explain, for example, the preference for investment in BOF technology in China over the 2000-2013 period, in addition to policy-related factors that may have induced the resulting capacity expansion. In contrast, where demand is more uncertain, EAF investment appears to be a more common choice. This may partially explain why EAF facilities expanded rapidly in the United States (U.S.) after the economic slowdown of the 1970s as well as the recent interest in EAF investment in China. However, while uncertainty may increase the incentive to invest in EAFs, it is unlikely to induce the exit of BOFs. It is also important to note that firms cannot react immediately to strong demand growth, given the long time needed to construct and install new equipment.

\subsubsection{Labour market rigidities and dismissal costs}

Labour market rigidities are also perceived to act as a barrier to exit. In a theoretical model by Poschke and Markus (2009[34] rigid employment protection legislation (EPL) results in higher firing costs and therefore discourages firms from exiting given the additional costs incurred immediately upon leaving the market. Moreover, the negative effect of EPL on exit is likely to be greater in industries where businesses face idiosyncratic demand shocks, as in the steel sector. Firms facing high labour costs are also less likely to experiment with new technologies, opting for more stable and older-vintage technologies, thereby lowering the probability of exit but also their potential competitiveness (Bottasso, Conti and Sulis, $\left.2017_{[35]}\right)$.

The empirical evidence on EPL rigidities and exit for firms in general is however mixed. Studies by Autor et al. $\left(2007_{[36]}\right)$ for the US and Kugler and Pica $\left(2008_{[37]}\right)$ for Italy find no statistically significant link between EPLs and exit. However, recent work by Bottasso, Conti and Sulis $\left(2017_{[35]}\right)$ uses data from thirteen OECD economies and finds evidence of a negative relationship between EPLs and exit. The negative relationship is found for both collective and individual dismissal types of regulations and the magnitude of the effect is stronger in industries with greater employee reallocation intensity.

Preliminary analysis based on OECD and James King plant-level data into the effects of EPLs on exit probability shows a negatively statistically significant link between more stringent EPLs and exit probability in the steel sector. In other words, available data suggest that more stringent collective dismissal regulations would seem to discourage exit. (Figure 6) 
Figure 6. Estimates of the probability of plant closures by Strictness of EPLs

$1998-2015$

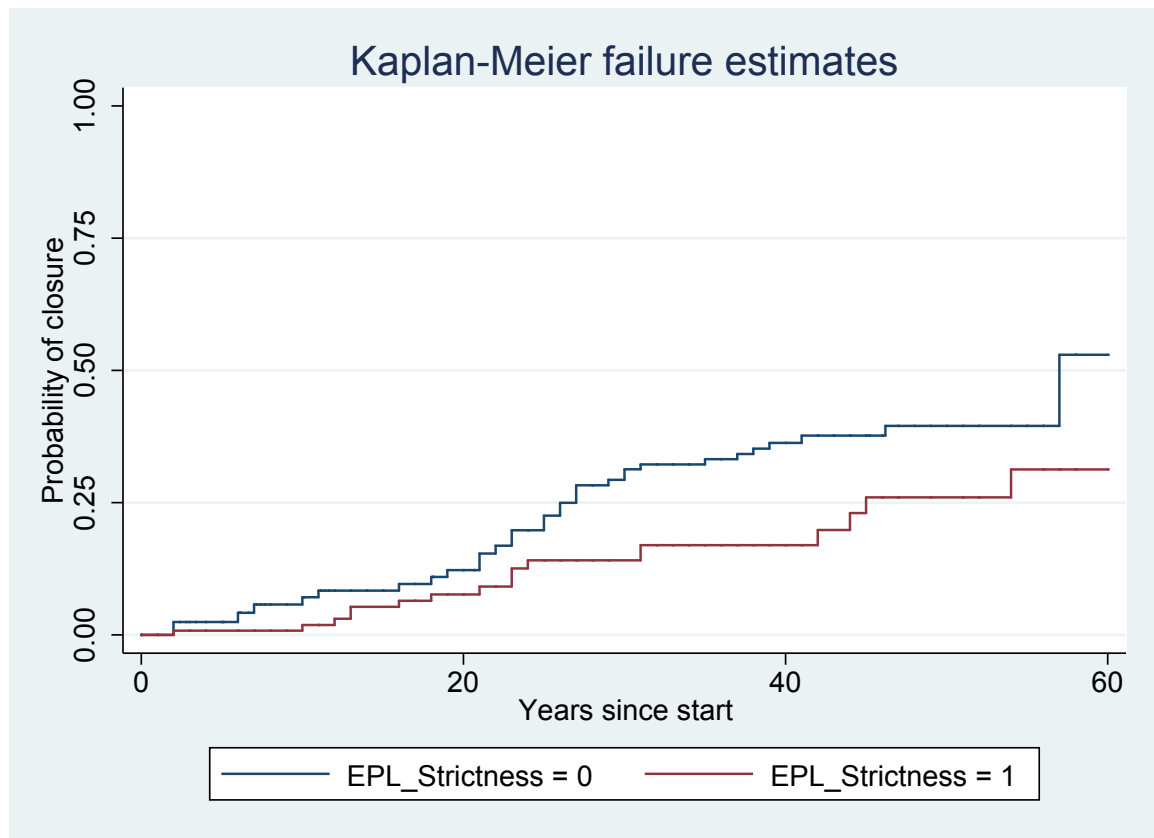

Note: The indicator of strictness of employment protection - collective dismissals (additional provisions) measures additional costs and procedures involved in dismissing more than one worker at a time (compared with the cost of individual dismissal).

Source: OECD calculations based on James King and OECD plant-level capacity database and OECD Employment and Labour Market Statistics database

In many OECD and non-OECD economies contractual obligations are in place to support workers in the event of an economic shock (OECD, 2018 $\left.8_{[38]}\right)$. While such contracts are important to assist workers when faced with dismissal, they can act as a barrier to exit since they can result in costs to the firm at the time of exit. Some of these obligations are contractual with the firm while others are contractual with the state and/or industry level. These costs include both written and unwritten obligations to provide employment and income security to workers, including severance payments, unemployment benefits, and pension obligations.

\subsubsection{Environmental costs associated with closures}

Stringent environmental regulations are important to address environmental concerns. However, their impact upon firm exit often depends on how these regulations are designed. In general, high clean-up costs following the decommissioning of a steelmaking plant may provide incentives to stay in business (i.e. act as a barrier to exit) while high environmental costs associated with ongoing production (e.g. a carbon tax) may give polluting steelmakers an incentive to exit. As concurrent policies could counter the effectiveness of either incentive, the need for coherence between environmental and industrial policy is key.

In theory, and as noted above, potentially large clean-up costs following the shutdown of steel facilities could provide an incentive for firms to delay closure in cases where plant exit would otherwise be profit-maximising (or loss-minimising). Indeed, the spectre of 
large clean-up costs may serve as an important exit barrier for individual plants, even when the environmental abatement cost of keeping such plants in operation is high.

But steel firms can also face ongoing penalties for violations of environmental regulation, notably emission related fines, for keeping activities in operation. Stringent environmental emission fines may thus incentivise firms to shut down heavy polluting plants in favour of those, which are more environmentally friendly. Hypothetically, the introduction of emissions fines (such as $\mathrm{CO}_{2}$ caps and emissions trading) may induce both the exit of older plants with greater pollution generating technologies. But again, such fines-along with any predicted abatement costs (i.e. mandated upgrades and future penalties) - may still be lower than the clean-up costs that the firm would face if the facility shut down.

Available empirical evidence for the steel sector suggests a positive relationship between environmental regulation and exit. Deily and Gray $\left(1991_{[39]}\right)$ find that plants were more likely to exit if they had a higher probability of facing heavier enforcement. More specifically, the results indicated that a 10 percent increase in the authors' environmental enforcement index increased the probability of a plant closing by 4.3 percentage points. Thus, a rise in regulatory stringency, all else equal, increased the likelihood of closure. Seemingly, the cost of compliance that is required in order for these facilities to continue operating exceeded the clean-up costs associated with exit.

Research using data for other sectors also suggests that more stringent regulation increases the likelihood of exit - see Snyder et al. $\left(2003_{[40]}\right)$ for chlorine manufacturing plants and Coysh et al. $\left(2019_{[41]}\right)$ for coal-fired power plants. It is important to note that older firms are more likely to use outdated and more polluting technologies and that many existing technology-based and performance based standards set more stringent standards for new than existing plants (Coysh et al., 2019 [41] $)$, which means that older, and more polluting plants often have lower opportunity costs for remaining in operation when compared to younger firms.

However, preliminary (i.e. non-structural) analysis on the relationship between various OECD indexes relative to environmental stringency and exit rates seems to suggest that stricter regulations are delaying exit. This is the case for example of the broad Environmental Policy Stringency (EPS) indicator (Figure 7), which is based on the degree of stringency of 14 environmental policy instruments, primarily related to climate and air pollution. This result clearly opposes previous empirical work and is likely to reflect the fact that other firm characteristics, which may be the cause of exit, are not taken into account in the analysis. For example, stricter environmental regulation that encourages steel companies to invest in energy efficiency can perhaps help sustain their economic viability during periods of high energy costs, or at least enhance their resiliency to energy price shocks. The causality link, therefore, may not be from environmental regulation per se, but rather from economic viability to the probability of exit. Otherwise, the result may be related to the fact that stricter environmental policy legislations may increase the costs of environmental clean-up more than the burden of compliance with environmental legislations. In other words, companies may prefer to pay the additional costs of operating more polluting plants rather than dealing with clean-up costs. An avenue for further analysis, therefore, would be to determine a causality nexus between environmental stringency and plant closures in the steel sector, by conducting econometric analysis that would also control for other factors including firm performance, country-specific institutional frameworks and other factors that are at the core of a firm's decision to exit the market. 
Figure 7. Estimates of the probability of plant closures by EPS

$1990-2015$

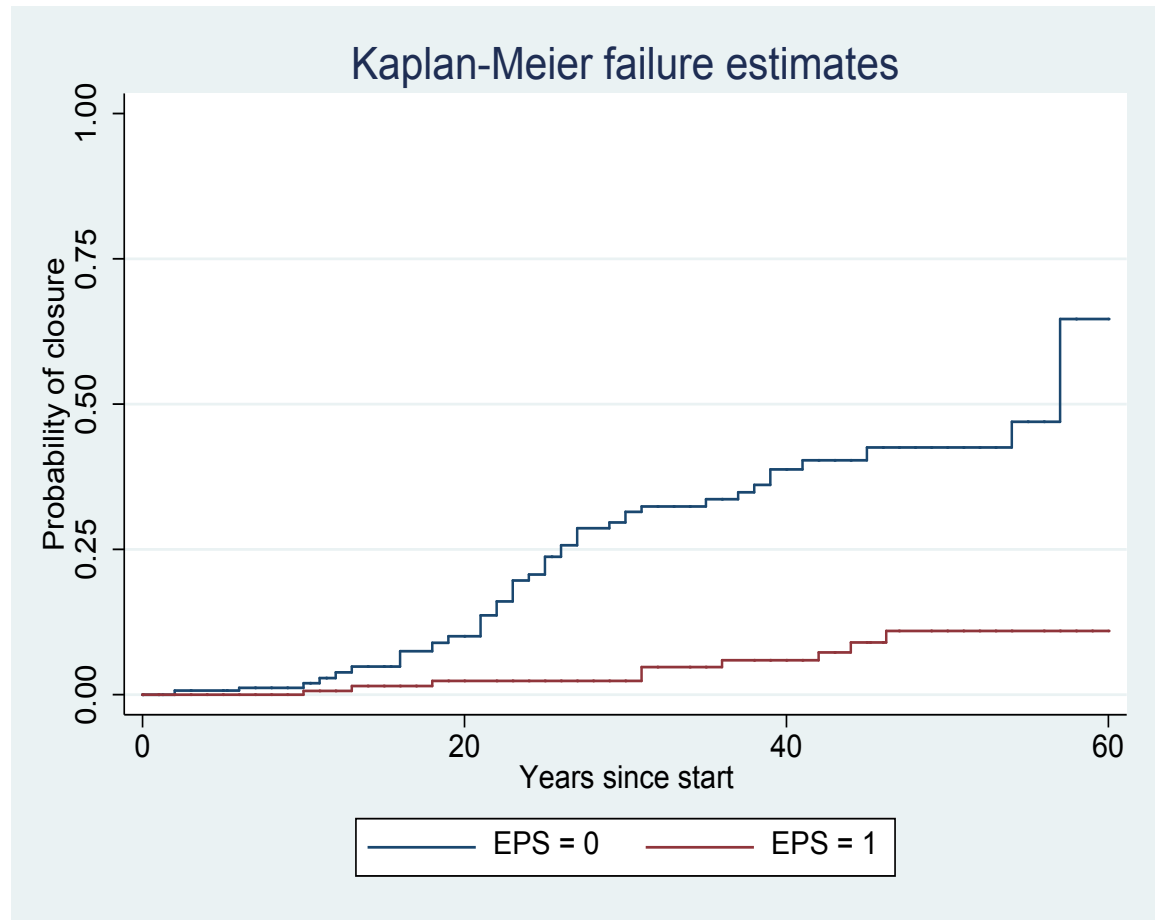

Note: The OECD Environmental Policy Stringency Index (EPS) is a country-specific and internationallycomparable measure of the stringency of environmental policy. Stringency is defined as the degree to which environmental policies put an explicit or implicit price on polluting or environmentally harmful behaviour. The index ranges from 0 (not stringent) to 6 (highest degree of stringency). The index covers 28 OECD and 6 BRIICS countries for the period 1990-2012. The index is based on the degree of stringency of 14 environmental policy instruments, primarily related to climate and air pollution. In this exercise, low levels of environmental stringency (e.g. index below 3 ) have been compared to high levels of environmental stringency (e.g. index above 3 ).

Source: OECD calculations based on James King and OECD plant-level capacity database and OECD Environmental policy database 


\section{Social, economic and geographic costs of closures}

Open market economies are characterised by continuous dynamism where firms are constantly entering, growing, shrinking and exiting the market. This process results in the reallocation of factors of production, including labour and capital to more productive plants away from less productive ones, contributing to aggregate productivity growth (Restuccia and Rogerson, 2013 $3_{[42]}$ ). Reallocation of workers from inefficient to more efficient parts of the economy may also benefit workers, insofar as the transition implies higher earnings in more efficient production units. When workers are displaced, however, this shift often involves spells of involuntary unemployment (Stock, 1998[43]). Efficiency gains and other aggregate benefits of restructuring are normally more diffused and therefore less visible than the costs imposed on workers of exiting or contracting firms, making the relevant reforms potentially difficult to implement politically (Andrews and Saia, 2017 $[44]$ ).

The economic and social costs of exits are particularly salient in the steel sector and other heavy industries, as steel companies tend to be larger and adjustments concentrated in time and geography. These include but are not limited to earnings lost by displaced workers into new jobs, the duration of unemployment, regional concentration and local economy spillovers, worker reallocation, and dismissed employee health. Much of the literature focuses on firms in general, however available studies pertaining to the steel sector specifically are presented below.

\subsection{Earnings losses and employment duration}

Mass lay-offs receive a great deal of attention from policy makers and the general public because of the challenges that affected workers face in finding re-employment (Silva et al., $\left.2019_{[45]}\right)$. This is particularly apparent for steel and other manufacturing workers as they tend to experience large wage reductions after they find new employment (Huttunen, $2018_{[46]}$; Bain, 1992 $\left.{ }_{[47]}\right)$.

In particular, a common finding in the economics literature is that displaced workers face considerable losses in the short run and these losses are persistent in the long run for employees both in steel and non-steel sectors. Looking at several sectors in the U.S., Jacobson, et al., (1993 [48] $)$ used administrative data for the state of Pennsylvania to study earning losses of displaced workers who exited plants that underwent a reduction in employment by $30 \%$ or more. Their results suggest that six years after, earnings declined by around $25 \%$ in comparison to pre-dismissal earnings if the workers' new jobs were in the same 4-digit industry and $18 \%$ in a different 4-digit manufacturing industry. They also find that earnings losses when displacement is not due to mass layoff are still 7-9\%. Couch and Placzek $\left(2010_{[49]}\right)$ use the same methodology, and the results are in line but show smaller magnitudes: earnings lost by displaced workers in Connecticut, U.S. six years after displacement were about $13 \%-15 \%$, i.e. very similar to what is found by Morissette et al. $\left(2013_{[50]}\right)$ in Canada.

Schmieder et al. (2007) performed a similar study for Germany and reported that workers displaced from their jobs during mass-layoffs in the 1982 recession suffered earnings losses of about $10 \%-15 \%$ that persisted 15 years after displacement. Recent work by Upward and Wright $\left(2019_{[51]}\right)$ relies on extensive data to provide new insights on dismissal and earnings loss of workers in the United Kingdom. Overall, their results find an immediate loss of 
income of roughly $40 \%$ and a long-term decrease of income by around $10 \%$. Moreover, unlike previous studies, earnings reductions in the long run are driven predominately by ex-post displacement earnings $(80 \%)$ as opposed to lower rates of employment.

Recent research by (Huttunen, 2018[46]) finds that displaced workers in the Finnish steel sector experienced persistent adverse effects on earnings following displacement. Moreover, those who found employment during the sample period experienced a decline in their earnings in comparison to the year before the displacement.

There are a number of different reasons why displaced workers would experience larger wage declines following re-employment, the most notable being associated with the fact that workers possess firm- or industry-specific skills - see e.g. Grundke et al. (2017 $\left.{ }_{[52]}\right)$; Silva et al. (2019 ${ }_{[45]}$ ) - particularly suited to their old jobs, which made them more productive and allowed them to be paid a wage premium. As such, there are costs associated with finding new work and these can differ depending on the occupation of the worker, exposure to automation and worker characteristics. In a cross-country study, Andrieu et al., $\left(2019_{[53]}\right)$ for example find that costs of transitions increase with, first, the cognitive ability of workers in origin job, second, the percentage of workers most likely to be displaced by automation in the manufacturing industry, and, third, the mean age of workers in the occupation.

Studies have also tracked the employment conditions of displaced steel and non-steel workers. Most of these studies find a considerable share of employees struggle to find employment after being laid off. A comprehensive analysis conducted by the New York State Department of Labor (1988) surveyed 3000 laid-off workers from Bethlehem Steel's Lackawanna plant, which experienced mass layoffs in the early 1980s. Three years after being laid off, only $38 \%$ were re-employed, while $34 \%$ were still searching for a new job, and $27 \%$ had opted for early retirement. Importantly, employees that performed tasks in the Bethlehem plant that were characterised as professional-managerial-technical were most successful in finding new work, followed by electricians and welders. This may be because such tasks were less steel-specific and involved transferable skills.

The empirical literature for both workers in general and in the steel sector in particular suggests that a large share of displaced workers remain unemployed for an extended period of time. The prospect of protracted unemployment for displaced steelworkers, like the prospect of substantial earnings losses, are very important socio-economic concerns that need to be addressed to minimise the resistance to closure and restructuring. Shorter unemployment duration would facilitate exit. Therefore, it is critical to deploy policies that help increase the likelihood of re-employment. The new OECD Jobs Strategy provides a structured framework to design comprehensive policy packages for workers facing labour market transitions $\left(\right.$ OECD, 2018 $\left.8_{[38]}\right) .{ }^{7}$ See Section 5. for a more detailed discussion on policy responses to displaced workers.

\subsection{Geographic concentration and reallocation}

There is growing interest in the role of geographic concentration of local industries on the plight of displaced workers. In the U.S., many of the steel plant closures were geographically concentrated in the ageing industrial regions of the Midwest. Europe also faced geographic concentration of steel plant closures in declining industrial regions. And

\footnotetext{
${ }^{7}$ Also see (OECD, 2019[73]) for a recent overview of labour market conditions across OECD economies.
} 
in many other parts of the world, steel plants have tended to be clustered near resources of raw materials, or in coastal areas with easy access to traded raw materials, or near downstream manufacturing industries that provided much of the demand for steel. Research has shown that displacement effects are more severe in declining local economies and industries (Jacobson, LaLonde and Sullivan, 1993 ${ }_{[48]}$; Carrington, 1993 [54]; Andersson et al., 2018[55]).

Geographic concentration of industries that utilise relatively similar skills might help displaced workers by giving them more employment opportunities-e.g. the case of the Australian mining industry's hiring of laid-off steelworkers of BlueScope (Andersson et al., 2018 $\left.8_{[55]}\right)$. This Australian study found that proximity to suitable jobs decreases joblessness, even within narrowly defined geographies. Furthermore, skill-related employment can induce workers to change industries, decreasing the likelihood of longterm unemployment. More generally, it appears that clusters of related activities not only create agglomeration externalities for firms but also for local workers.

A recent study by Nefkke et al. (2018) examined the re-employment of displaced workers stemming from plant closure and analysed the possible impact of industry concentration of the displaced industry as well as different industries that utilise the same skills as the predisplacement industry. The results are general and non-steel specific. Importantly, displaced workers experience relatively smaller earnings losses and find new work faster if there is a geographical concentration of firms of the same industry (potentially requiring similar skills). In contrast, the presence of large local industries (but different to the industry of mass layoff) that are skill-related to the industry of the closed plant, is found to be associated with larger earnings losses but better re-employment prospects over the longerterm. The loss in earnings is likely associated with small differences between the skillrelated industries, thus, even though these workers may have shorter unemployment spells, the skills match will not be frictionless compared to jobs in the pre-displacement industry, resulting in lower salaries. These results suggest that in regions lacking concentrations of skill-related industries or regions where skill-related industries are in decline, geographic relocation by workers may serve as the best opportunity for re-employment.

Instances of mass layoffs in the steel industry are indeed found to be linked with increases in migration by displaced workers seeking new jobs (Bednarzik and Szalanski, 2012 [56]; Dotson and Perera, 2016 ${ }_{[57]}$; O'Brien and Burrows, 2017 [58]), particularly in regions without the presence of other industries which could provide economic stability. Locations with a larger economic diversity will normally better support the shock of mass layoffs.

\subsection{Health and other social consequences}

Besides the lost earnings and increased unemployment duration, numerous studies show that displacement has a negative impact on health. Brand $\left(2015_{[59]}\right)$ summarises the widespread evidence on the negative effects of job loss, which include not only subsequent unemployment, long-term earnings losses, and lower job quality, but also declines in psychological and physical well-being, social withdrawal, family disruption, lower levels of children's attainment and well-being. Studies have linked job losses to short and longterm declines in physical health, including worse self-reported health, physical disability, cardiovascular disease, a greater number of reported medical conditions, increase in hospitalization, higher use of medical services, higher use of disability benefits, an increase in self-destructive behaviours and suicide, and mortality (Brand, 2015 ${ }_{[59]}$ ). 
In Sweden, Eliason and Storrie $\left(2009_{[60]}\right)$ find that the mortality risk following plant shutdowns in 1987-1988 increased $44 \%$ for men during the first four years after displacement, primarily due to alcohol-related conditions and suicide, but no effect on female mortality was found. Browning and Heinesen $\left(2012_{[61]}\right)$ also show that mortality in Denmark rises after displacement, with a $84 \%$ increase just after plant closure, and decreasing thereafter, but still 10\% higher after 20 years. Black, Devereux and Salvanes $\left(2015_{[62]}\right)$ study the impact of plant closings and mass layoffs on the health of Norwegian workers and find that displacement has a negative effect on cardiovascular health of both men and women, with much of the effect driven by an increase in smoking

Sullivan and Wachter $\left(2009_{[63]}\right)$ studied the impact of job displacement on mortality of workers in the U.S. state of Pennsylvania during the 1970s and 1980s. Their empirical results indicate that displacement during the early and mid-1980s increased the mortality rate of high-seniority male workers by $50-100 \%$ shortly after displacement, and remained $10-15 \%$ higher twenty years after displacement. Moreover, the rates of mortality were greater for workers with larger earnings losses. It is relevant to note that roughly $29 \%$ of displaced workers in this study were from the steel industry. In fact, the Mon Valley suburb of Pittsburgh, which faced heavy steel job losses in the 1980s, was reported in 1985 to have a suicide rate twice the national average (Bednarzik and Szalanski, 2012[64]).

In a study conducted using a panel of U.S. states from 1996 to 2005 Classen and Dunn ((2012[64]) find that job losses associated to mass layoffs, which typically occur as a result of plant closure, are positively associated with the suicide rate for males and females. Their empirical results estimate one additional suicide death for every 4200 males who become unemployed as part of a mass-layoff and one additional suicide death for every 7100 females who lose their job as a result of a mass-layoff. They list as possible explanation the fact that, in case of mass layoffs, the prospects of finding a new job may be worse, or that a large number of social networks may be fractured. Indeed, entire towns may experience an emotional trauma from a plant closing, suggesting sociological forces could be at play (Classen and Dunn, 2012[64]).

Most recently, the socioeconomic literature has been looking at the impact of mass layoffs on steelworkers communities. A notable example comes from the United Kingdom where Mc Lachlan (2019 $\left.{ }_{[65]}\right)$ studies the loss of status associated with the loss of employment. Loss of status adds up to the negative impacts on individuals and contribute to the creation of a shared narrative within the steelworker occupational community to cope with the trauma of employment loss. 


\section{Past policy approaches}

One guideline of the Steel Committee is to make every effort to provide effective programmes to assist steel workers affected by structural adjustments (encouraging readaptation to alternative employment). In view of the need to exchange information on policies and programmes to assist steel workers, section 5.1 below focusses extensively on labour market policies applied across some countries. Section 5.2 summarises, very briefly, the restructuring experiences and policies adopted by selected jurisdictions. Although restructuring policies, broadly speaking, have focussed more on ensuring the viability of firms and addressing excess capacity, and have not necessarily aimed at removing barriers to exit, some linkages can be made with the latter. At the end of every historical example provided in section 5.2, a summary is provided which links each historical experience with the factors identified in the literature as influential in facilitating or hampering exit.

\subsection{Labour-market policies to address displaced workers}

The new OECD Jobs Strategy provides a structured framework to design a comprehensive policy package to assist workers in the face of labour market transformations (OECD, 2018[66]).

Active labour market policies (ALMP), which support workers in their job search and include re-training and up-skilling possibilities, appear to have some success in bringing displaced workers back into employment. Overall, increased spending on ALMP (measured as a percentage of GDP) has been found to correlate with a higher percentage of re-employment one year after displacement (Andrews and Saia, 2017 $[67]){ }^{8}$

In some cases of mass lay-off events ${ }^{9}$, dedicated agencies have been set up to better assist workers, improving access to job-search assistance and counselling (OECD, 2018 ${ }_{[68]}$ ). For example, the mass displacement of steelworkers in Pittsburgh helped initiate two major U.S. Department of Labor programs launched in 1988 - the Economic Development and Worker Adjustment Assistance Act (EDWAA) and the Worker Adjustment and Notification Retraining Act (WARN) (Bednarzik and Szalanski $\left(2012_{[69]) .}{ }^{10}\right.$ Additionally, the Department of Labor currently administers a number of active employment and training programs that provide benefits and services to individuals impacted by mass layoffs. These include:

\footnotetext{
${ }^{8}$ The analysis does not account for the quality of the policy.

${ }^{9}$ Mass layoffs are often perceived by policymakers as bringing about the most serious social consequences, thus the interest in preventive and tailor made measures.

${ }^{10}$ EDWAA provided funds to States and local sub-state grantees so they can help dislocated workers find and qualify for new jobs, the program no longer exists. WARN offers protection to workers, their families and communities by requiring employers with 100 or more employees to provide notice 60 days in advance of covered plant closings and covered mass layoffs.
} 
Trade Adjustment Assistance for Workers Program (authorized under the Trade Act of 1974), which provides workers who are adversely affected by foreign trade with opportunities to obtain skills, credentials, resources, and support necessary for reemployment (U.S. Department of Labour, 2020[70]).

Dislocated Worker Formula Program (authorized under the Workforce Innovation and Opportunity Act, WIOA), which aids dislocated workers to obtain re-employment through job search assistance, career services, and skills training. Under the WIOA, a National Dislocated Worker Grant Program expands state and local capacity to provide services to workers affected by significant dislocation events (U.S. Department of Labor, 2020 [71]). Also authorized under WIOA, the Department provides a Rapid Response service - a strategy designed to respond to layoffs and plant closings by quickly coordinating services and providing immediate aid to affected workers (U.S. Department of Labor, 2020 [72]).

Social organisations can play a vital role during the notification period in facilitating support measures to employees that will be dismissed. One example includes the Swedish Job Security Councils (JSCs). The councils are based on collective agreements between the social organisers in a sector or occupational field, such as white-collar workers in the private sector. JSCs are actively involved in each phase of restructuring, from giving guidance to firms and trade unions at the early phase in addition to transition services and support to employees that are dismissed. Transitionary support can include individual counselling, career planning, job-search support, retraining and so on (OECD, 2019 [73]; Silva et al., $\left.2019_{[45]}\right)$. Amongst OECD members, Sweden has one of the highest rates of reemployment of displaced workers at roughly $90 \%$ (OECD, 2019 [73])].

Life-long learning, re-training and activation policies can improve re-employment prospects and need to be part of a comprehensive strategy to support workers (OECD, $2018_{[74]}$ ). Continuous training throughout a worker's professional life is fundamental as employees face increasingly fragmented employment histories and are expected to be able to adopt to changing work environments. Learning possibilities need to be broadly available and independent of a workers employment history in order to be effective (OECD, $\left.2018_{[74]}\right)$.

The need for continuous up-skilling is particularly important in view of increasing automation of production processes and tasks, notably for workers that carryout routine tasks Nedelkoska and Quintini $\left(2018_{[75]}\right.$ ) (Frey and Osborne, 2017 ${ }_{[76]}$ ); (Graetz and Michaels, 2018 $\left.{ }_{[77]}\right)$. Moreover, these measures to support workers are all the more critical in a mature industry like steel, where structural adjustment pressures might be higher. 11 In addition, training might be especially important for low and medium-skilled workers, who are likely to face a higher risk of displacement but at the same time are however less likely to benefit from training possibilities (OECD, 2018 $\left.8_{[74]}\right)$.

\footnotetext{
${ }^{11}$ Bednarzik and Szalanski (2012) note that one of the most successful vocational programs provided to displaced steel workers in Pittsburgh involved robotics training developed by the Allegheny County Community College in partnership with Westinghouse. The Community College received the funding and hired Westinghouse personnel to help design the curriculum and teach the course, using expensive Westinghouse equipment in the training. This was an intense 1,064 hour program for the students who were rigorously screened through testing and interviewing, with a pool of 400 applicants, enticed by the prospect of high-paying jobs, reduced to 20 per class.
} 
An extensive study on the effectiveness of training programmes by Nedelkoska and Quintini $\left(2012_{[64]}\right)$ showed that programmes that were small scale, linked to the local job market, and focused on developing analytical skills are particularly helpful in increasing the likelihood of getting a job. The analysis also illustrated that subsidising the relevant community college is positively associated with re-employment, although very few workers in their sample ever returned to their previous earnings' level, especially when taking into account fringe benefits.

An evaluation by Winter-Ebmer $\left(2006_{[78]}\right)$ of a training program for displaced Austrian steelworkers that utilises a treatment/control methodology found that the program increased earnings and employment. The author noted that payment for the programme was shared by the worker, the government, and the firm, and involved job counselling, search activities, and training. Also, unemployment benefits were allowed to continue during training for up to four years.

Facilitating regional mobility (e.g. by addressing distortions in housing markets) could also help displaced workers. More specifically, studies have indicated that individuals who relocated after displacement were 7-15 percentage points more likely to be re-employed after firm closure compared to immobile displaced workers (Jolly, 2015 [79]). As such, policies that facilitate mobility may increase the re-employment of displaced workers stemming from plant closure. However, while workers who move to a different region after displacement are more likely to become re-employed (Andrews and Saia, 2017 [67]), many non-job related considerations (e.g. family ties, regulation of the housing market) are important factors that also influence mobility (Huttunen, Møen and Salvanes, 2018 ${ }_{[80]}$; OECD, 2018[68] $)$.

With regard to the timing of activation policies, it is found that early interventions are more efficient in better preparing workers to find employment. The design of these policies should however refrain from preventing or delaying the closure of inefficient production units. Searching and re-training for a new job can take time, so starting ALMPs before the actual lay-off increases the chances of a smooth job transition. Implementing activation measures as soon as workers are notified helps avoid long periods of unemployment that result in lower future wages and re-employment prospects (OECD, 2018 [74] $_{\text {; Andrews and }}$ Saia, 2017 $[67])$ due to skill depreciation and signalling effects. Regulation can facilitate earlier interventions. Pre-notification periods for lay-offs differ substantially among OECD countries $\left(\mathrm{OECD}, 2018_{[68]}\right)$. While mandating extremely long notice periods can have disadvantages for companies (e.g. signalling companies' challenges, reducing workers' motivation), a minimum notice period provides better possibilities for meaningful proactive measures (OECD, 2018 $\left.8_{[68]}\right)$.

\subsection{Examples of restructuring and policies relevant for exit}

In response to steel crises, many episodes of industry restructuring have taken place over the past decades, with policies either directly or indirectly relevant for exit. At times, governments have taken an active role in managing the restructuring process (e.g., in Europe in the 1970s and early 1980s), while other experiences show the adjustment being left more to market forces without specifically tailored government restructuring programmes (e.g., Europe during later stages of restructuring and the U.S.) (OECD, $\left.2005_{[81]}\right)$. In many economies, the privatisation of the industry may have had important implications for exit; indeed, government ownership in steel mills can lead to overinvestment and the maintenance of steel facilities which would otherwise exit the market. 


\subsubsection{European Union steel industry restructuring: $1980 \mathrm{~s}$}

The 1970s was a difficult period for the European steel industry, as it was for steel industries in many other regions due to oil shocks that depressed economic activity and steel demand. As a result of falling steel prices and heavy losses, the European Commission introduced a number of measures in the late 1970s to address the crisis, including optional guidelines on prices of steel and bilateral agreements with major steel-exporting countries to voluntarily restrain deliveries to the Common Market. However, the situation in the industry did not improve, because the voluntary engagements did not hold and prices were not maintained (OECD, 2005 [81]).

After a temporary recovery of the European steel market in 1979, the situation deteriorated again, and, in October 1980, the Commission declared a state of "manifest crisis" in the steel sector. To address the manifest crisis, the Commission prepared the Steel Industry Restructuring Plan 1980-1985 ${ }^{12}$ that provided for the control of the market through quotas on steel production, minimum prices and voluntary agreements. This was further complemented by a broader approach to tackle social and economic concerns.

A number of important measures were adopted to strengthen competitive conditions in the European steel industry, including i) the prohibition of all subsidies to the steel industry as from 1986, with the exception of subsidies for plant closures, R\&D and social and regional interventions, ii) European Coal and Steel Community loans at favourable interest rates were made available for modernisation and investments, iii) the provision of financial support under the Regional Development Fund for creating new economic activities in other sectors of the economy, and iv) under the Social Fund, the provision of training and re-education programmes, as well as programmes to cover the costs of relocation of steel workers, redundancies and early retirement (OECD, 2005 $\left.{ }_{[81]}\right)$.

This combination of policies was key to the success of the restructuring process during this period and allowed significant capacity reductions over the period of five years, in net terms. At the end of the Steel Industry Restructuring Plan, the capacity reductions were even greater than initially envisaged, even taking into account the investments made in new steel facilities and the modernisation of existing facilities. Between 1980 and 1988, when the restructuring plans for the then new Member States Greece, Portugal and Spain expired, crude steelmaking capacity in the EU12 declined from 222 million tonnes to 188 million tonnes $(15.3 \%)$, while employment in the steel sector declined by almost $40 \%$, from 672 000 in 1980 to 409000 in 1988 (OECD, 2005 [81]).

The re-allocation and re-adaptation of workers was a main concern for European policymakers throughout the restructuring process. The European Commission granted around ECU 5 billion of state aid, of which more than 2 billion was used to support labour reductions. In addition, considerable financing was dedicated for redeployment; from 1981 to 1986 around ECU 0.5 billion was provided for redeployment of more than 180000 workers. Moreover, loans with favourable interest rates were made available to support job creation in other sectors and to encourage investment in small and medium-sized businesses. During the year 1985 alone, the European Commission spent ECU 145 million alone on roughly 53 thousand workers in the steel sector.

In sum, the policy experience included two key points posited as important by the literature on exit: the removal and prohibition of subsidies and the reduction of social costs associated

12 The plan is also known as Davignon Plan II. 
with exit. Relevant to limiting social costs were targeted policies such as funding for new economic activities to absorb affected workers, training and re-education programmes, worker relocation and redundancies, and early retirement.

\subsubsection{Japanese steel industry restructuring: $1980 \mathrm{~s}$}

Structural adjustment in the Japanese steel industry followed major economic shocks such as, for example the two oil shocks in the 1970s, and the yen appreciation that followed the Plaza accord in 1985. During these crisis periods, the Japanese government implemented temporary measures to alleviate the consequences of the crisis and address some of the industry's structural deficiencies. At the same time, companies voluntarily implemented a number of measures to develop a more efficient business structure.

Government involvement in the early phases of restructuring took initiatives that were dependent on the adopted steelmaking production process. On the one hand, the government supported the voluntary modernisation and rationalisation efforts made by companies operating BOF plants through more favourable tax and business regimes. On the other hand, the government intervened directly to adjust capacity and output volumes of EAF plants (JISF, 2017 ${ }_{[82]}$ ).

Under the Industry Stabilisation Act of 1978 and the Structural Improvement Act of 1983, the devised measures included for example the provision of debt guarantees to companies in need of funds to achieve their voluntary restructuring efforts. Moreover only companies or facilities in industries classified as unprofitable were eligible for government assistance. In the case of EAF producers, the government specifically provided them with a facility to deal with excess capacity. Moreover, companies were not able to build new facilities and were required to keep pace in reducing production. Finally, to facilitate mergers and acquisitions designated companies were excluded from the application of the anti-trust law. Further legislation was enacted with the goal of facilitating business collaboration including concentration and mergers of enterprises among companies, as well as to promote investment in the modernisation of facilities and technological development.

In parallel, the government undertook a number of measures to mitigate the social adjustment costs associated with restructuring. As for the rationalisation process relative to $\mathrm{BF} / \mathrm{BOF}$ facilities, the government devised a special fund for labour adjustment within its economy-wide employment insurance system to provide training and partially fund temporary transfers. Workers in EAF facilities were specifically targeted in the employment adjustment benefit system, which included financial support for retired workers and workforce re-training.

Finally, further measures were enacted through the Act on Temporary Measures for Facilitating Industrial Structure Adjustment in 1987 which comprised two main pillars: 1) countermeasures for specific companies and 2) countermeasures for specific regions. These policies entailed setting up a fund to provide low-interest rate loans and a special tax measure to companies or regions which suffered from oversupply or financial deterioration mainly due to a sharp appreciation of the yen.

Mapping the Japanese experiences of the $1970 \mathrm{~s}-80$ s to exit barriers, three measures are noteworthy, two aimed at high capital costs and high social costs (see sections 3.3.1, and 4.2), and one with implications for competition. To achieve higher industry concentration, competition regulation was relaxed, in particular by limiting the applicability of anti-trust regulation. In the government plan, the newly consolidated entities would reallocate resources towards the most profitable operations, ultimately promoting the managed exit 
of the most unprofitable. On sunk costs, in order to favour exits and limit the hampering effects of high sunk costs, the Japanese authorities instituted a facility to alleviate the burden of sunk costs, albeit targeted specifically at EAF operators, who face relatively lower capital costs. Finally, on social costs, the government shouldered some of the social costs of restructuring by assisting regions and companies, with funds for economic diversification.

\subsubsection{United States steel industry restructuring: early 2000s}

The Asian financial crisis of 1997-1998, and its spread to other emerging markets, had significant effects on the U.S. steel industry, creating steel import surges that reduced steel prices down to levels at which steel could no longer be produced profitably in the U.S. By mid-1998, U.S. companies were losing substantial market share to imports, and many previously profitable domestic steelmakers experienced a decline in sales revenue, operating income, and profits during 1998 and 1999. Some small companies experienced a loss of access to capital and liquidity problems, which forced some of them into bankruptcy (Cooney, 2003 [83]).

The U.S. government's general policy was to let the market be the ultimate arbiter in determining how the U.S. steel industry adjusted. To complement this policy, the government adopted other steps to further industry restructuring and capacity reductions (OECD, 2002[84]). In 2002, the Bush Administration announced a three-pronged strategy to address the structural problems facing the steel industry, involving i) the initiation of a safeguard investigation under Section 201 of the Trade Act of 1974, ii) efforts with trading partners to eliminate inefficient excess capacity worldwide, and iii) negotiations seeking stronger disciplines aimed at reducing or eliminating trade-distorting government subsidies to the steel sector (OECD, 2005 [81]).

After a nine-month investigation, relief under Section 201 was put in place for up to three years, to be reviewed at mid-term to determine if it was still necessary. A stated goal of the Bush Administration in applying the Section 201 tariffs was to provide a period of respite from import competition, so the industry could restructure through consolidation and other measures, and better meet international competition. In 2002, some mini-mill operators moved rapidly to restructure their side of the steel business. For example, in May 2002 Nucor, already by far the largest U.S. mini-mill operator, acquired Birmingham Steel, the financially troubled second largest U.S. steel mini-mill operator. Nucor had earlier acquired Trico, a mini-mill from the state of Alabama with capacity of more than 1 million in which LTV had an ownership stake, through the LTV bankruptcy proceedings (Cooney, 2003 [83]).

Restructuring of integrated steelmakers was slowed by political disagreements on how to deal with the so called "legacy costs" ${ }^{13}$ These legacy costs constituted a significant drag on the integrated steelmakers' competitiveness. Estimates suggested that legacy costs consumed approximately $14 \%$ of the weighted average price of a tonne of steel (Bruno, 2005). From an industrial consolidation perspective, legacy costs constituted a significant class of liabilities that discouraged merger and acquisitions given that acquiring companies had little interest in supporting large numbers of retirees. To overcome this challenge and allow buyers to shed the accumulated pension benefits, the U.S. government (the Pension

\footnotetext{
${ }^{13}$ Legacy costs are defined as pension and health care benefit provisions of steel worker contracts, which provide benefits beyond those available through public entitlements and that are funded by the earnings of steel companies (Cooney, 2003[83]).
} 
Benefit Guarantee Corp.) assumed liabilities for pensions at five steel firms totalling 250,000 retirees with more than USD 8 billion in liabilities (Crandall, 2013 [85]). Legacy costs became less of a barrier to consolidation also as companies went through the bankruptcy process and shed those costs, by switching to defined contribution plans as part of their Chapter 11 restructuring efforts (OECD, 2002 [84]).

The bankruptcy process thus played a major role in restructuring the U.S. steel industry in the late 1990s and early 2000s. Effective bankruptcy regimes can facilitate the exit of unviable firms and affect the competitive process of entry and exit. In the late 1990s and early 2000s, tens of U.S. steel companies declared bankruptcy. Some were able to restructure under Chapter 11 of the bankruptcy law but others were unable to do so and were forced to liquidate their assets. The restructuring and consolidation experience led to significant employment reductions in the U.S. steel industry between 2000 and 2005, exceeding $25 \%$, according to OECD figures. In addition, labour agreements were renegotiated during the course of the industry's consolidation, giving steel companies greater flexibility. Consolidation through mergers seems to have provided the U.S. steel industry with an important channel through which to restructure; merged companies were able introduce job descriptions that increased worker flexibility, alter entitlements benefits, and reduce the manager/production worker ratio (OECD, 2008[86]). Steelmaking capacity in the U.S. also declined during this period.

The U.S. restructuring experience suggests an approach characterised by limited government barriers to industry restructuring and the closure of inefficient steelmaking capacity, and touches on the broader exit framework in important ways. First, the bankruptcy process played a major role, encouraging the exit of non-viable firms and restructuring of viable ones. Many companies ceased operations, while others emerged from bankruptcy or were acquired by other companies. Second, the decision to raise tariffs to provide domestic producers with some relief in order to regroup and restructure has implications for the competitive environment in the U.S. steel industry. Third, state aid in the US appears to have played a smaller role and market forces appear to have played a greater role in promoting exit of unprofitable operators. A notable exception is the shouldering of pension and healthcare liabilities to facilitate the purchase of distressed steelmakers. On the one hand, this measure appears to have eased the social costs of layoffs at closures. On the other hand, it might have allowed indebted steelmakers to be acquired in a process of industry concentration.

\subsubsection{Privatisation of the steel industry and exit}

Across the OECD and many important non-OECD steel-producing economies, such as Brazil and Russia, state ownership of steel companies has declined over recent decades, and today remains very limited. In several emerging economies, however, fully or partly state-owned steel companies are still in the marketplace through government actions to, e.g., convert debt into equity.

A number of concerns have been raised regarding the possible behaviour of state-owned steel companies with respect to their investments and exit decisions vis à vis private competitors, and whether their decisions are market-based or reflect pre-defined policy goals (Mattera and Silva, 2018[87])The potential for government decisions regarding investment and exit to weigh indirect social factors more heavily than would be the case under private ownership, and for state-owned enterprises to enjoy advantages over their private competitors, are important for exit. These factors can lead to the maintenance of steelmaking facilities that, from a business perspective, should be closed. 


\section{Possible policy recommendations for discussion}

For competition to be effective in the steel industry, steel producers must be allowed to enter and exit the steel market in response to changing market conditions. Barriers to exit weaken the effects of market forces that would normally reallocate resources from one firm or market to another. Some exit barriers are the result of cost structures of steel firms, which do not reflect government interventions as such. Other barriers are policy-induced, and contribute to structural excess capacity.

The fact that the global steel industry continues to experience persistent excess capacity, and that the industry has underperformed in terms of profitability and productivity compared to most other upstream and downstream industries, indicates that policy factors, including subsidies and other government support measures, may have discouraged the "optimal" exit of the least productive steel plants. Such measures hamper the process of restructuring that is necessary for the steel industry, and have adverse effects on competition, innovation and productivity, and the long-term economic viability of the sector.

Markets - not governments - should drive the restructuring process, so that steel production and trade reflect the underlying market-based competitive positions of steel producers. Governments can however play a supportive role in the restructuring process, for example by assisting the workers and communities affected by the plant closures. By promoting market-based restructuring, the Steel Committee can encourage more efficient use of resources in steel-producing economies, with positive impacts on the overall productivity and economic performance of the sector.

Allowing inefficient plants to shut down in response to market forces can nevertheless be politically difficult, as the plants may be large employers that are concentrated in regions whose economies depend on them. The social costs of closures thus tend to be highly concentrated and visible, which can spur strong opposition to restructuring and result in significant political costs for the policy maker involved in the process. The perception that other jurisdictions are using unfair policy measures to the benefit of their industry may also weighs on the politics of plant closures. Commitments to accepted guidelines can help in this regard, as well as increasing public awareness that postponing the necessary restructuring imposes large financial costs on public administrations and diverts limited public resources that could be used more effectively, including on programmes that would help mitigate the associated social costs of the plant closures.

An international dimension also adds to the costs of postponing restructuring and preventing exits over the longer term. In addition to contributing to structural excess capacity, governments that cede to political pressure to keep inefficient steel producers from shutting down risk introducing measures that distort trade. This can create repercussions for steel producers abroad, with the potential for increased trade actions, or possibly even the introduction of new support measures, to protect the steel industry in other jurisdictions. A vicious cycle can then ensue, creating further financial difficulties for steel producers around the world and prolonging the period needed for restructuring.

Against a background of slowing steel demand growth globally, and the heightened risks that now cloud the global steel market outlook, governments around the world may again face increased political pressure to keep inefficient steel producers from shutting down and exiting the market. It may be warranted for policy makers to enhance transparency of 
policy-induced exit barriers, and encourage the reform, removal or avoidance of measures that prevent exit from occurring.

Previous OECD work going beyond the steel sector has discussed policy reforms to encourage the restructuring and exit of weak firms in order to boost overall productivity across economies. This research has highlighted for example several features of insolvency regimes that potentially impose barriers to restructuring. Addressing such barriers can help promote restructuring of ailing firms and encourage exit.

In addition, government support measures such as grants awards and cost refunds, preferential loans, equity infusions and conversion, tax benefits, input and output support can delay the exit of even the worst performing steel producers. These measures may sufficiently reduce the variable costs of the company, reduce the cost of capital by sustaining the investments necessary for a continuous upgrading of the firm's capital assets, or create significant demand for the steel products of the company. By doing so subsidies and other support measures alter the market mechanisms that should govern the exit of inefficient producers from the market.

Based on the analysis of exit barriers in this paper, the following recommendations may help governments to enhance competition and the productive potential of their own steel sectors, while contributing to healthier market conditions globally.

When looking at the universe of support measures that governments can provide to steel producers, attention should be paid to avoid those measures that delay exit more significantly:

- Measures with the specific purpose of preventing exit and that are provided to firms close to a state of bankruptcy or consistently making losses. These are instruments for debt relief, debt to equity conversion and for debt restructuring, which significantly improve firms' solvency ratios and prevent their exit.

- Measures of varying purpose and nature that alleviate firms' operating costs and provide financial resources to cushion losses during periods of downturns. These instruments include cash grants, loans and guarantees as well as tax benefits, input and output support.

- Measures aimed at supporting capital investments, which alleviate firms' capital costs but are not linked to any enforceable criteria to monitor the offsetting of regulations that would otherwise put firms at a competitive disadvantage (e.g. environmental compliance). Irrespective of the link with specific enforceable criteria, these measures, in any case, may delay the exit of firms that would not have been able to comply with regulations absent such support.

- Indirect measures such as lax enforcement of regulations (e.g. environmental legislation), can provide some leeway for firms to continue their operations in spite of adverse market conditions by reducing the variable costs associated with compliance. In addition, weak enforcement of bankruptcy legislation undermines the very same rules that ensure the orderly exit of inefficient firms from the market.

To ensure an orderly and market-based exit of inefficient steel-producers from the market, governments should therefore refrain from providing measures specifically geared to assist firms in financial and operational distress, and, to the extent possible, refrain from providing measures with the purpose of, or unintended consequence to, alleviating firms' operating costs or capital expenditures. 
Support measures provided should be temporary, so that they do not provide a permanent lifeline to unviable steel firms or promote expansion of their capacity. Moreover, there should be strict criteria for, and monitoring of, any such measures introduced.

There are some support measures that, under certain terms and conditions, may encourage exit. Support to facilitate the permanent closure of steel plants and assistance to workers are the most relevant. However, any government support measures provided for closures should be monitored carefully to ensure that they result in the permanent closure of capacity. In other words, such aid should be carefully defined and limited. Efforts to facilitate privatisation may also deserve consideration given concerns that government ownership of steel mills can lead to over-investment and/or the maintenance of facilities that would otherwise close if governments did not influence decision-making or exert other forms of control.

Reforms that accelerate restructuring and promote exit in the steel industry also carry significant social costs, which should be addressed as part of the efforts to encourage adjustment in the steel industry. Active labour market policies that support job training and employment search can help displaced workers return to work, and these policies are likely to be particularly effective in areas where other sectors (besides steel) are growing or where barriers to firm entry are low, allowing new firms to enter the market and grow.

Government support to contain the social costs of exits occurring in the steel sector should follow the following guidelines:

- Government programmes to mitigate the social costs of restructuring should focus on support to the affected workers and should not translate into subsidies to the companies, as the latter could be used to maintain excess capacity. The funds of such programmes should not be provided to companies, but to other entities with a clearly defined mandate, or to workers directly.

- Support to workers should not lock them into the declining facilities and should, instead, facilitate transition workers into other activities. This could be achieved by a combination of policies to help workers acquire new skills, active labour market policies to assist with their job search, and effective social protection to support them during the transition period.

- In this context, careful consideration should be given to training programmes. Training programs that are small scale, linked to the local job market, and focused on developing analytical/math/science/technical skills should be encouraged. Training programs that involve screening and matching workers with the training curriculum, and measures to audit training after it has begun, have been shown to be effective.

- Broader policies that might help alleviating the socioeconomic costs of geographically concentrated closures may include targeted regional development policies, or policies that can facilitate labour reallocation and mobility across regions (and countries).

- With regard to the timing of activation policies, it is found that early interventions are more efficient in better preparing workers to find employment. Firms should also be encouraged to effectively communicate with their workers facing displacement. Provide counselling that fully informs them of financial benefits, as well as available re-employment strategies. 
- Support for privatisation should result in an outcome of privatisation where the government or relevant public body no longer has effective control of the entity. The privatisation transactions and procedures should be transparent and at fair market values. 


\section{Conclusions}

Barriers to exit in the steel industry are significant and require attention due to their negative impacts on excess capacity. Especially, asset specific and sunk costs are important barriers to exit in the steel industry. But exit barriers stem also from government interventions hindering the closure of inefficient or unviable steel plants. In addition, exits may entail important costs associated with redundancy payments to workers, environmental clean-up, and operations to dismantle the mills. Moreover, the companies can incur operating losses between the announcement and actual closure of the plant.

Closures entail costs for local, regional or state governments. These may include foregone tax revenues, labour force training programmes for workers made redundant, as well as local economy spillovers and the associated support programmes to help generate new economic activity in the affected communities. Some governments may also incur the costs of financing the closure of the steel mills themselves. Given the various market- and policyrelated exit barriers, unprofitable and inefficient production units can remain in the market for a long period of time.

In addition to removing subsidies and other government support measures that hinder the exit of inefficient steel firms from the market, policymakers can play a significant role in promoting adjustment by assisting steel workers that are displaced in the process. The challenges associated with getting laid-off steelworkers back to work include the fact that steel workers tend to be older, with firm and industry-specific skills. It is often difficult for steel workers to find employment elsewhere at a wage that matches what they earned working in the steel sector. Thus, displaced steelworkers spend more time being unemployed after displacement, and they face steeper wage losses when they are reemployed.

Thus, perhaps the greatest challenge that the industry and policymakers face is how they can effectively transition steel workers to new employment. This paper discussed some evidence of retraining programs, which have had a mixed record of success, but seem to work better when they teach quantitative and technical skills, especially if these skills are a good match for both the job market and the worker. The paper also discussed wage supplements, which should theoretically speed up the return to employment, but there is little evidence of the efficacy or even participation in these programs.

There is also a considerable degree of heterogeneity amongst displaced workers. Some displaced steelworkers are simply not likely to return to work, regardless of employment assistance options that might be available to them. However, a large share of workers will find new employment, and for these workers, offering training programs, wage supplements, and other active market labour policies (ALMPs) remains an important strategy for facilitating re-employment. This includes facilitating re-location, since there is evidence that displaced workers that relocate have less dramatic wage losses and shorter unemployment spells, when compared to workers that are not mobile. Moreover, regions where employment opportunities entail more closely related tasks and skills offer better reemployment opportunities for laid off steel workers. 


\section{References}

Adalet McGowan, M., D. Andrews and V. Millot (2017), "Insolvency Regimes, Technology Diffusion and Productivity Growth : Evidence from Firms in OECD Countries”, OECD Economics

Department Working Papers, No. 1425, OECD Publishing, Paris, https://dx.doi.org/10.1787/36600267-en.

Adalet McGowan, M., D. Andrews and V. Millot (2017), "Insolvency regimes, zombie firms and capital reallocation”, OECD Economics Department Working Papers, No. 1399, OECD Publishing, Paris, https://dx.doi.org/10.1787/5a16beda-en.

Adalet McGowan, M., D. Andrews and V. Millot (2017), “The Walking Dead?: Zombie Firms and Productivity Performance in OECD Countries”, OECD Economics Department Working Papers, No. 1372, OECD Publishing, Paris, https://dx.doi.org/10.1787/180d80ad-en.

Adalet McGowan, M., D. Andrews and V. Millot (2017), “The Walking Dead?: Zombie Firms and [1 Productivity Performance in OECD Countries”, OECD Economics Department Working Papers, 87 No. 1372, OECD Publishing, Paris, https://dx.doi.org/10.1787/180d80ad-en.

Aghion, P. et al. (2018), The Inverted-U Relationship Between Credit Access and Productivity Growth, Banque de France, https://scholar.harvard.edu/files/aghion/files/invertedu relationship.pdf (accessed on 25 June 2019).

Aghion, P., T. Fally and S. Scarpetta (2007), "Credit constraints as a barrier to the entry and postentry growth of firms", Economic Policy, Vol. 22/52, pp. 732-779, http://dx.doi.org/10.1111/j.1468-0327.2007.00190.x.

Aitken, B. and A. Harrison (1999), "Do Domestic Firms Benefit from Direct Foreign Investment? Evidence from Venezuela”, American Economic Review, Vol. 89/3, pp. 605-618, http://dx.doi.org/10.1257/aer.89.3.605.

Alfaro, L. et al. (2004), "FDI and economic growth: the role of local financial markets", Journal of International Economics, Vol. 64/1, pp. 89-112, https://www.sciencedirect.com/science/article/pii/So022199603000813 (accessed on 25 June 2019).

Amann, E. and F. Nixson (1999), "Globalisation and the Brazilian Steel Industry: 1988-97”, The Journal of Development Studies, Vol. 35/6, pp. 59-88, https://www.tandfonline.com/doi/abs/10.1080/00220389908422602.

Andersson, F. et al. (2018), "Job Displacement and the Duration of Joblessness: The Role of Spatial Mismatch", The Review of Economics and Statistics, Vol. 100/2, pp. 203-218, http://dx.doi.org/10.1162/REST a 00707.

Andrews, D., M. Adalet McGowan and V. Millot (2017), "Confronting the zombies : Policies for productivity revival”, OECD Economic Policy Papers, No. 21, OECD Publishing, Paris, https://dx.doi.org/10.1787/f14fd801-en. 
Andrews, D., M. McGowan and M. Valentine (2017), Confronting the zombies: Policies for productivity revival, https://www.oecd-ilibrary.org/economics/confronting-thezombies f14fd801-en (accessed on 30 August 2019).

Andrews, D. and A. Saia (2017), "Coping with creative destruction: Reducing the costs of firm exit”, [4 OECD Economics Department Working Papers, No. 1353, OECD Publishing, Paris, https://dx.doi.org/10.1787/bbb44644-en.

Andrews, D. and A. Saia (2017), "Coping with creative destruction: Reducing the costs of firm exit", [6 OECD Economics Department Working Papers, No. 1353, OECD Publishing, Paris, https://dx.doi.org/10.1787/bbb44644-en.

Andrews, D. and A. Saia (2016), "OECD iLibrary | Coping with creative destruction: Reducing the costs of firm exit”, No. 1353, OECD, Paris, https://www.oecd-ilibrary.org/economics/copingwith-creative-destruction bbb44644-en (accessed on 17 June 2019).

Andrews, D. and A. Saia (2016), "OECD iLibrary | Coping with creative destruction: Reducing the costs of firm exit”, No. 1353, OECD, Paris, https://www.oecd-ilibrary.org/economics/copingwith-creative-destruction bbb44644-en (accessed on 17 June 2019).

Andrieu, E. et al. (2019), "Occupational transitions: The cost of moving to a "safe haven"”, OECD Science, Technology and Industry Policy Papers, No. 61, OECD Publishing, Paris, https://dx.doi.org/10.1787/6d3fobff-en.

Åslund, A. (1999), Why Has Russia's Economic Transformation Been So Arduous?, Carnegie Endowment for International Peace, https://carnegieendowment.org/1999/04/28/why-hasrussia-s-economic-transformation-been-so-arduous-pub-201.

Autor, D., W. Kerr and A. Kugler (2007), "Does Employment Protection Reduce Productivity? Evidence from US States”, The Economic Journal, Vol. 117/521, pp. F189-F217, http://dx.doi.org/10.1111/j.1468-0297.2007.02055.x.

Bain, T. (1992), Banking the Furnace: Restructuring of the Steel Industry in Eight Countries, W.E. Upjohn Institute, http://dx.doi.org/10.17848/9780880995399.

Bain, T. (1992), Banking the Furnace: Restructuring of the Steel Industry in Eight Countries, W.E. Upjohn Institute, http://dx.doi.org/10.17848/9780880995399.

Bain, T. (1992), Banking the Furnace: Restructuring of the Steel Industry in Eight Countries, W.E. Upjohn Institute for Employment Research, Kalamazoo, Michigan, http://dx.doi.org/10.17848/9780880995399.

Beck, T. and A. Demirguc-Kunt (2006), "Small and medium-size enterprises: Access to finance as a growth constraint”, Journal of Banking and Finance, Vol. 30, pp. 2931-2943, http://dx.doi.org/10.1016/j.jbankfin.2006.05.009.

Bednarzik, R. and J. Szalanski (2012), "An Examination of the Work History of Pittsburgh Steelworkers, Who Were Displaced and Received Publicly-Funded Retraining in the Early 1980s", IZA Discussion Paper, No. 6429, IZA, https://papers.ssrn.com/sol3/papers.cfm?abstract id=2031997 (accessed on 26 February 2019). 
Bednarzik, R. and J. Szalanski (2012), An Examination of the Work History of Pittsburgh Steelworkers, Who Were Displaced and Received Publicly-Funded Retraining in the Early 1980s, http://ftp.iza.org/dp6429.pdf (accessed on 17 June 2019).

Bednarzik, R. and J. Szalanski (2012), "An Examination of the Work History of Pittsburgh Steelworkers, Who Were Displaced and Received Publicly-Funded Retraining in the Early 1980s", IZA Discussion Paper, No. 6429, IZA, https://papers.ssrn.com/sol3/papers.cfm?abstract id=2031997 (accessed on 26 February 2019).

Bernard, A. et al. (2007), "Firms in International Trade", Journal of Economic Perspectives, Vol. 21/3, pp. 105-130, http://dx.doi.org/10.1257/jep.21.3.105.

Biorn, E., R. Golombec and A. Raknerud (1995), "Environmental Regulations and Plant Exit: A Logit Analysis Based on Establishment Panel Data”, Memorandum, https://ideas.repec.org/p/hhs/osloec/1995 036.html (accessed on 17 June 2019).

Black, S., P. Devereux and K. Salvanes (2015), "Losing Heart? The Effect of Job Displacement on Health”, ILR Review, Vol. 68/4, pp. 833-861, http://dx.doi.org/10.1177/0019793915586381.

Blonigen, B., B. Liebman and W. Wilson (2013), "Antidumping and Production-Line Exit: The Case of the US Steel Industry”, Review of Industrial Organization, Vol. 42/4, pp. 395-413, http://dx.doi.org/10.1007/s11151-013-9387-7.

Blonigen, B., B. Liebman and W. Wilson (2013), “Antidumping and Production-Line Exit: The Case of the US Steel Industry”, Review of Industrial Organization, Vol. 42/4, pp. 395-413, http://dx.doi.org/10.1007/s11151-013-9387-7.

Blonigen, B., B. Liebman and W. Wilson (2013), "Antidumping and Production-Line Exit: The Case of the US Steel Industry”, Review of Industrial Organization, Vol. 42/4, pp. 395-413, http://dx.doi.org/10.1007/s11151-013-9387-7.

Blonigen, B., B. Liebman and W. Wilson (2013), "Antidumping and Production-Line Exit: The Case of the US Steel Industry", Review of Industrial Organization, Vol. 42/4, pp. 395-413, https://www.jstor.org/stable/43550411?seq=1\#metadata info tab contents (accessed on 17 June 2019).

Blonigen, B. and W. Wilson (2010), “Foreign subsidization and excess capacity”, Journal of International Economics, Vol. 80/2, pp. 200-211, http://dx.doi.org/10.1016/J.JINTECO.2009.10.001.

Bloom, N. et al. (2016), "Trade Induced Technical Change? The Impact of Chinese Imports on Innovation, IT and Productivity", The Review of Economic Studies, Vol. 83/1, pp. 87-117, http://dx.doi.org/10.1093/restud/rdvo39.

Bloom, N., M. Schankerman and J. Reenen (2013), "Identifying Technology Spillovers and Product Market Rivalry”, Econometrica, Vol. 81/4, pp. 1347-1393, http://dx.doi.org/10.3982/ECTA9466.

Bloom, N., M. Schankerman and J. Van Reenen (2013), "Identifying Technology Spillovers And Product Market Rivalry”, Econometrica, Vol. 81/4, pp. 1347-1393, 
http://dx.doi.org/10.3982/ECTA9466.

Bloom, N., M. Schankerman and J. Van Reenen (2013), "IDENTIFYING TECHNOLOGY SPILLOVERS AND PRODUCT MARKET RIVALRY”, Econometrica, Vol. 81/4, pp. 1347-1393, $[1$ http://dx.doi.org/10.3982/ECTA9466.

Bogardus, K. (2007), Bankrupt companies avoid more than $\$ 700$ million in cleanup costs, The Center for Public Integrity, https://publicintegrity.org/environment/bankrupt-companiesavoid-more-than-700-million-in-cleanup-costs/ (accessed on 24 June 2019).

Botta, E. and T. Koźluk (2014), "Measuring Environmental Policy Stringency in OECD Countries: A Composite Index Approach”, OECD Economics Department Working Papers, No. 1177, OECD Publishing, Paris, https://dx.doi.org/10.1787/5jxrjnc45gvg-en.

Bottasso, A., M. Conti and G. Sulis (2017), "Firm dynamics and employment protection: Evidence from sectoral data", Labour Economics, Vol. 48, pp. 35-53, http://dx.doi.org/10.1016/J.LABECO.2017.05.013.

Brand, J. (2015), "The Far-Reaching Impact of Job Loss and Unemployment.", Annual review of sociology, Vol. 41, pp. 359-375, http://dx.doi.org/10.1146/annurev-soc-071913-043237.

Bravo-Biosca, A., C. Criscuolo and C. Menon (2013), "What Drives the Dynamics of Business Growth?”, OECD Science, Technology and Industry Policy Papers, No. 1, OECD Publishing, Paris, https://dx.doi.org/10.1787/5k486qtttq46-en.

Browning, M. and E. Heinesen (2012), "Effect of job loss due to plant closure on mortality and hospitalization", Journal of Health Economics, Vol. 31/4, pp. 599-616, http://dx.doi.org/10.1016/J.JHEALECO.2012.03.001.

Carreira, C. and F. Silva (2010), "NO DEEP POCKETS: SOME STYLIZED EMPIRICAL RESULTS ON FIRMS' FINANCIAL CONSTRAINTS”, Journal of Economic Surveys, Vol. 24/4, pp. 731753, http://dx.doi.org/10.1111/j.1467-6419.2009.00619.x.

Carrington, W. (1993), "Wage Losses for Displaced Workers: Is It Really the Firm That Matters?”, Journal of Human Resources, Vol. 28/3, pp. 435-462, https://econpapers.repec.org/article/uwpjhriss/v_3a28_3ay_3a1993_3ai_3a3_3ap_3a435462.htm (accessed on 26 June 2019).

Classen, T. and R. Dunn (2012), "The effect of job loss and unemployment duration on suicide risk in the United States: a new look using mass-layoffs and unemployment duration", Health Economics, Vol. 21/3, pp. 338-350, http://dx.doi.org/10.1002/hec.1719.

Collard-Wexler, A. and J. De Loecker (2015), "Reallocation and Technology: Evidence from the US Steel Industry”, American Economic Review, Vol. 105/1, pp. 131-171, http://dx.doi.org/10.1257/aer.20130090.

Conway, P. and G. Nicoletti (2006), "Product Market Regulation in the non-manufacturing sectors of OECD Countries: Measurement and Highlights”, No. 530, OECD, Paris, http://www.oecd.org/eco/ (accessed on 25 June 2019).

Cooney, S. (2003), The American Steel Industry: A Changing Profile, Congressional Research 
Service.

Couch, K. and D. Placzek (2010), "Earnings Losses of Displaced Workers Revisited", American Economic Review, Vol. 100/1, pp. 572-589, http://dx.doi.org/10.1257/aer.100.1.572.

Couch, K. and D. Placzek (2010), "Earnings Losses of Displaced Workers Revisited", American Economic Review, Vol. 100/1, pp. 572-589, http://dx.doi.org/10.1257/aer.100.1.572.

Coysh, D. et al. (2019), "Vintage differentiated regulations and plant survival: Evidence from coalfired plants", OECD Environment Working Papers, No. 144, OECD Publishing, Paris, https://doi.org/10.1787/31621ca6-en.

Crandall, R. (2013), Structural Adjustment in the U.S. Steel Industry. and Market Structure: Investigating Catalysts for Entry and Exit, https://trace.tennessee.edu/utk graddiss/4971 (accessed on 17 June 2019).

Davis, S. and T. von Wachter (2011), "Recessions and the Cost of Job Loss", No. 17638, National Bureau of Economic Research, Cambridge, MA, http://dx.doi.org/10.3386/w17638.

D'Costa, A. (1999), The global restructuring of the steel industry : innovatons, institutions, and industrial change, Routledge.

De Backer, K. and L. Sleuwaegen (2003), "Does Foreign Direct Investment Crowd Out Domestic Entrepreneurship?”, Review of Industrial Organization, Vol. 22/1, pp. 67-84, http://dx.doi.org/10.1023/A:1022180317898.

Deily, M. (1991), “Exit Strategies and Plant-Closing Decisions: The Case of Steel”, The RAND Journal of Economics, Vol. 22/2, p. 250, http://dx.doi.org/10.2307/2601021.

Deily, M. (1991), "Exit Strategies and Plant-Closing Decisions: The Case of Steel”, The RAND Journal of Economics, Vol. 22/2, pp. 250-263, http://dx.doi.org/10.2307/2601021.

Deily, M. (1988), “Exit Barriers in the Steel Industry”, Economic Review, Federal Reserve of Cleveland, http://clevelandfed.org/research/review/.

Deily, M. (1988), "Investment Activity and the Exit Decision", The Review of Economics and Statistics, Vol. 70/4, p. 595, http://dx.doi.org/10.2307/1935822.

Deily, M. (1988), "Investment Activity and the Exit Decision", The Review of Economics and Statistics, Vol. 70/4, p. 595, http://dx.doi.org/10.2307/1935822.

Deily, M. and W. Gray (1991), "Enforcement of pollution regulations in a declining industry", Journal of Environmental Economics and Management, Vol. 21/3, pp. 260-274, http://dx.doi.org/10.1016/0095-0696(91)90030-M.

Djankov, S. (2016), "Simeon Djankov The Doing Business project: how it started: correspondence Article (Published version)”, Journal of Economic Perspectives, Vol. 30/1, p. 2, http://dx.doi.org/10.1257/jep.30.1.247.

Dotson, C. and N. Perera (2016), "The Rise and Fall of a Great American City: Gary, Indiana", 
Bhumi, The Planning Research Journal, Vol. 5/1, p. 12, http://dx.doi.org/10.4038/bhumi.v5i1.21.

Dotson, C. and N. Perera (2016), "The Rise and Fall of a Great American City: Gary, Indiana", Bhumi, The Planning Research Journal, Vol. 5/1, p. 12, http://dx.doi.org/10.4038/bhumi.v5i1.21.

Dunlevy, J. (1980), A Test of the Capacity Pressure Hypothesis Within a Simultaneous Equations Model of Export Performance, https://www.jstor.org/stable/pdf/1924281.pdf (accessed on 8 January 2019).

Eaton, B. and R. Lipsey (1980), "Exit Barriers are Entry Barriers: The Durability of Capital as a Barrier to Entry", The Bell Journal of Economics, Vol. 11/2, p. 721, http://dx.doi.org/10.2307/3003391.

Eliason, M. and D. Storrie (2009), "Does Job Loss Shorten Life?", Journal of Human Resources, Vol. 44/2, pp. 277-302, http://dx.doi.org/10.3368/jhr.44.2.277.

Elsevier Science (Firm), A. et al. (2008), Labour economics., North Holland, https://econpapers.repec.org/article/eeelabeco/v 3a15 зау за2008 заi за1 зар за7895.htm (accessed on 25 June 2019).

Fons-Rosen, C. et al. (2013), Quantifying Productivity Gains from Foreign Investment, National Bureau of Economic Research, Cambridge, MA, http://dx.doi.org/10.3386/w18920.

Fons-Rosen, C. et al. (2013), Quantifying Productivity Gains from Foreign Investment, National Bureau of Economic Research, Cambridge, MA, http://dx.doi.org/10.3386/w18920.

Franco, C. and J. Weche Gelübcke (2015), "The Death of German Firms: What Role for Foreign Direct Investment?", The World Economy, Vol. 38/4, pp. 677-703, http://dx.doi.org/10.1111/twec.12227.

Frey, C., M. change and U. 2017 (n.d.), "The future of employment: how susceptible are jobs to computerisation?", Elsevier, https://www.sciencedirect.com/science/article/pii/So040162516302244 (accessed on 26 June 2019).

Frey, C. and M. Osborne (2017), "The future of employment: How susceptible are jobs to computerisation?”, Technological Forecasting and Social Change, Vol. 114, pp. 254-280, http://dx.doi.org/10.1016/J.TECHFORE.2016.08.019.

GFSEC (2017), Global Forum on Steel Excess Capacity Berlin Ministerial Report, GFSEC, Berlin, https://www.bmwi.de/Redaktion/EN/Downloads/global-forum-on-steel-excess-capacityreport.pdf? blob=publicationFile (accessed on 10 August 2020).

Global Forum on Steel Excess Capacity (2017), Report, https://www.bmwi.de/Redaktion/EN/Downloads/global-forum-on-steel-excess-capacityreport.pdf? blob=publicationFile.

Golombec, R. and A. Raknerud (1997), "Do Environmental Standards Harm Manufacturing Employment?”, The Scandinavian Journal of Economics, Vol. 99/1, pp. 29-44, 
http://dx.doi.org/10.1111/1467-9442.00045.

Graetz, G. and G. Michaels (2018), "Robots at Work”, The Review of Economics and Statistics, Vol. 100/5, pp. 753-768, http://dx.doi.org/10.1162/rest a 00754 . Journal of Asian Economics, Vol. 48, pp. 148-159, http://dx.doi.org/10.1016/J.ASIECO.2016.10.006.

Grundke, R. et al. (2017), "Having the right mix: The role of skill bundles for comparative advantage and industry performance in GVCs", OECD Science, Technology and Industry Working Papers, No. 2017/o3, OECD Publishing, Paris, https://dx.doi.org/10.1787/892a4787en.

Harrigan, K. (1982), "Exit Decisions in a Mature Industries", Academy of Management Journal, Vol. 25/4, pp. 707-732.

Harrigan, K. (1982), “Exit Decisions in Mature Industries.”, Academy of Management Journal, Vol. 25/4, pp. 707-732, http://dx.doi.org/10.2307/256095.

Harrison, A., L. Martin and S. Nataraj (2011), "Learning Versus Stealing: How Important Are Market-Share Reallocations To India’s Productivity Growth?”, No. 16733, National Bureau of Economic Research, http://www.nber.org/papers/w16733 (accessed on 18 June 2019).

Harrison, A., L. Martin and S. Nataraj (2011), "Learning Versus Stealing: How Important Are Market-Share Reallocations To India's Productivity Growth?”, No. 16733, National Bureau of Economic Research, http://www.nber.org/papers/w16733 (accessed on 18 June 2019).

Haskel, J., S. Pereira and M. Slaughter (2007), "Does Inward Foreign Direct Investment Boost the Productivity of Domestic Firms?”, Review of Economics and Statistics, Vol. 89/3, pp. 482-496, http://dx.doi.org/10.1162/rest.89.3.482.

Helland, E. (1998), “The Enforcement of Pollution Control Laws: Inspections, Violations, and SelfReporting”, Review of Economics and Statistics, Vol. 80/1, pp. 141-153, http://dx.doi.org/10.1162/003465398557249.

Helpman, E., M. Melitz and S. Yeaple (2004), “Export Versus FDI with Heterogeneous Firms”, American Economic Review, Vol. 94/1, pp. 300-316, http://dx.doi.org/10.1257/000282804322970814.

Helpman, E., M. Melitz and S. Yeaple (2004), “Export Versus FDI with Heterogeneous Firms”, American Economic Review, Vol. 94/1, pp. 300-316, http://dx.doi.org/10.1257/000282804322970814.

Helpman, E., M. Melitz and S. Yeaple (2004), “Export Versus FDI with Heterogeneous Firms”, American Economic Review, Vol. 94/1, pp. 300-316, http://dx.doi.org/10.1257/000282804322970814.

Hijzen, A., R. Upward and P. Wright (2010), "The Income Losses of Displaced Workers", The Journal of Human Resources, Vol. 45/1, pp. 243-269, https://www.jstor.org/stable/pdf/20648942.pdf?refreqid=excelsior\%3A9424036cb2a39cf27f81 
6cead69b86do (accessed on 18 June 2019).

Howell, T. et al. (1988), Steel and the State: Government Intervention and Steel's Structural Crisis, Westview Press, Boulder and London.

Huttunen, K. (2018), Consequences of Job Displacement, Workshop on Facilitating Structural Adjustment in the Steel Sector, 2018, http://www.oecd.org/industry/ind/Huttunen OECD 9 2018.pdf (accessed on 3 July 2019).

Huttunen, K., J. Møen and K. Salvanes (2018), “Job Loss and Regional Mobility”, Journal of Labor Economics, Vol. 36/No. 2, pp. 479-509, https://doi.org/10.1086/694587.

Huttunen, K., J. Møen and K. Salvanes (2018), “Job Loss and Regional Mobility”, Journal of Labor Economics, Vol. 36/2, pp. 479-509, http://dx.doi.org/10.1086/694587.

Ichino, A. et al. (2017), “Too old to work, too young to retire?”, The Journal of the Economics of Ageing, Vol. 9, pp. 14-29, http://dx.doi.org/10.1016/J.JEOA.2016.07.001.

Jacobson, L., R. LaLonde and D. G. Sullivan (2005), "Estimating the returns to community college schooling for displaced workers", Journal of Econometrics, Vol. 125/1-2, pp. 271-304, http://dx.doi.org/10.1016/J.JECONOM.2004.04.010.

Jacobson, L., R. LaLonde and D. Sullivan (2005), "Do Displaced Workers Benefit from Community College Courses? Findings from Administrative Data and Directions for Future Research", SSRN ${ }^{29}$ Electronic Journal, http://dx.doi.org/10.2139/ssrn.1020996.

Jacobson, L., R. LaLonde and D. Sullivan (1993), “Earnings Losses of Displaced Workers”, The American Economic Review, Vol. 83/4, p. 25, https://www.jstor.org/stable/pdf/2117574.pdf?refreqid=excelsior\%3A7ac980offfee4ofogabaea o75f8d6635 (accessed on 17 June 2019).

Jacobson, L., R. LaLonde and D. Sullivan (1993), "Earnings Losses of Displaced Workers”, The American Economic Review, Vol. 83/4, pp. 685-709, http://www.jstor.org/stable/2117574.

Jacobson, L., R. LaLonde and D. Sullivan (1993), “Earnings Losses of Displaced Workers”, The American Economic Review, Vol. 83/4, pp. 685-709, https://www.jstor.org/stable/pdf/2117574.pdf?refreqid=excelsior\%3A7ac980offfee4ofogabaea 075f8d6635 (accessed on 17 June 2019).

Jacobson, L., R. LaLonde and D. Sullivan (1993), "Earnings Losses of Displaced Workers", The American Economic Review, Vol. 83/4, pp. 685-709, http://www.jstor.org/stable/2117574.

Jacobson, L., R. Lalonde and D. Sullivan (1993), "Earnings losses of displaced workers revisited", American Economic Review, Vol. 83/4, pp. 685-709.

Javorcik, B. (2004), "Does Foreign Direct Investment Increase the Productivity of Domestic Firms? In Search of Spillovers Through Backward Linkages", American Economic Review, Vol. 94/3, pp. 605-627, http://dx.doi.org/10.1257/0002828041464605.

JISF (2017), Restructuring of the Japanese Steel Industry.

Jolly, N. (2015), “Geographic Mobility and the Costs of Job Loss", Journal of Economic Analysis 
and Policy, Vol. 15/4, pp. 1793-1829, http://dx.doi.org/10.1515/bejeap-2014-0131.

Jolly, N. (2015), "Geographic Mobility and the Costs of Job Loss", Journal of Economic Analysis and Policy, Vol. 15/4, pp. 1793-1829, http://dx.doi.org/10.1515/bejeap-2014-0131.

Jones, G. (2019), “European Court condemns Italy for pollution at Ilva steel plant”, Reuters, https://www.reuters.com/article/us-italy-pollution-court/european-court-condemns-italy-forpollution-at-ilva-steel-plant-idUSKCN1PI2PM (accessed on 24 June 2019).

Jones, G. (2019), "European Court condemns Italy for pollution at Ilva steel plant”, Reuters, https://www.reuters.com/article/us-italy-pollution-court/european-court-condemns-italy-forpollution-at-ilva-steel-plant-idUSKCN1PI2PM (accessed on 24 June 2019).

Kalinova, B., A. Palerm and S. Thomsen (2010), “OECD's FDI Restrictiveness Index: 2010 Update”, [1 OECD Working Papers on International Investment, No. 2010/3, OECD Publishing, Paris, 44 https://dx.doi.org/10.1787/5km91po2zj7g-en.

Keller, W. and S. Yeaple (2009), “Multinational Enterprises, International Trade, and Productivity Growth: Firm-Level Evidence from the United States", Review of Economics and Statistics, Vol. 91/4, pp. 821-831, http://dx.doi.org/10.1162/rest.91.4.821.

Kneller, R. and M. Pisu (2007), “Industrial Linkages and Export Spillovers from FDI”, The World Economy, Vol. 30/1, pp. 105-134, http://dx.doi.org/10.1111/j.1467-9701.2007.00874.X.

Kokko, A. and T. Thang (2014), "Foreign Direct Investment and the Survival of Domestic Private Firms in Viet Nam", Asian Development Review, Vol. 31/1, pp. 53-91, http://dx.doi.org/10.1162/ADEV a 00025 .

Kokko, A. and T. Thang (n.d.), Foreign Direct Investment and the Survival of Domestic Private Firms in Viet Nam, https://www.mitpressjournals.org/doi/pdf/10.1162/ADEV a 00025 (accessed on 26 July 2019).

Kovalishina, G. (2002), “Почему металлургические компании не выходят на рынок ценных бумаг?”, Institute for Financial Studies, http://www.ifs.ru/publications/author/?author=127.

Kugler, A. and G. Pica (2008), "Effects of employment protection on worker and job flows: Evidence from the 1990 Italian reform", Labour Economics, Vol. 15/1, pp. 78-95, http://dx.doi.org/10.1016/J.LABECO.2006.11.002.

Lachlan, C. (2019), How steelworker communities cope with restructuring, https://business.leeds.ac.uk/research-ceric/dir-record/research-blog/1510/how-steelworkercommunities-cope-with-restructuring (accessed on 23 April 2020).

LaLonde, R., L. Jacobson and D. Sullivan (2005), "Do Displaced Workers Benefit from Community College Courses? Findings from Administrative Data and Directions for Future Research", SSRN Electronic Journal, http://dx.doi.org/10.2139/ssrn.1020996.

Lambson, V. (1991), "Industry evolution with sunk costs and uncertain market conditions", International Journal of Industrial Organization, Vol. 9/2, pp. 171-196, http://dx.doi.org/10.1016/S0167-7187(05)80001-3.

Leana, C. and J. Ivancevich (1987), “Involuntary Job Loss: Institutional Interventions and a . 
Research Agenda”, Academy of Management Review, Vol. 12/2, pp. 301-312, http://dx.doi.org/10.5465/amr.1987.4307847.

Leigh, D. (1994), Retraining displaced workers : the US experience, Training Policies and Programme Development Branch, International Labour Office, https://eric.ed.gov/?id=ED371115 (accessed on 26 February 2019).

Leigh, D. (1990), Does Training Work for Displaced Workers?: A Survey of Existing Evidence, W.E. Upjohn Institute for Employment Research, Kalamazoo, Michigan, http://dx.doi.org/10.17848/9780880995481.

List, J., W. McHone and D. Millimet (2004), "Effects of environmental regulation on foreign and domestic plant births: is there a home field advantage?", Journal of Urban Economics, Vol. 56/2, pp. 303-326, http://dx.doi.org/10.1016/J.JUE.2004.03.007.

Locker/Albrecht Associates (1985), Report to the United Steelworkers of America on the effectiveness of retraining programs for displaced Chicago steelworkers, AFI-CIO.

Mattera, G. and F. Silva (2018), "State enterprises in the steel sector", OECD Science, Technology and Industry Policy Papers, No. 53, OECD Publishing, Paris, https://dx.doi.org/10.1787/2a8adgcd-en.

McGowan, M., D. Andrews and V. Millot (2017), "Insolvency regimes, zombie firms and capital reallocation", No. 1399, OECD, Paris, https://www.oecd-ilibrary.org/docserver/5a16bedaen.pdf?expires $=1561537715 \& i d=i d \& a c c n a m e=0$ eid $84004878 \&$ checksum $=$ B372CCE22A10D3F8 66658CE9CE4303D3 (accessed on 26 June 2019).

Meager, N. (2009), "The role of training and skills development in active labour market policies", International Journal of Training and Development, Vol. 13/1, pp. 1-18, http://dx.doi.org/10.1111/j.1468-2419.2008.00312.x.

Melitz, M. (2003), "The Impact of Trade on Intra-Industry Reallocations and Aggregate Industry Productivity", Econometrica, Vol. 71/6, pp. 1695-1725, http://dx.doi.org/10.1111/14680262.00467.

Millimet, D., S. Roy and A. Sengupta (2009), "Environmental Regulations and Economic Activity: Influence on Market Structure”, Annual Review of Resource Economics, Vol. 1/1, pp. 99-118, http://dx.doi.org/10.1146/annurev.resource.050708.144100.

Montero, A. (1998), "State Interests and the New Industrial Policy in Brazil: The Privatization of Steel, 1990-1994", Latin American Politics \& Society, Vol. 40/3, http://dx.doi.org/10.1111/J.1548-2456.1998.TBooo62.X.

Morissette, R. (2013), “The risk and cost of job loss in Canada, 1978-2008”, Canadian Journal of Economics, Vol. 46(4), pp. 1480-1509.

Myers, J. (2018), “EPA, U.S. Steel reach $\$ 75$ million deal to fix Duluth mill site”, Duluth News Tribune, https://www.duluthnewstribune.com/news/4492023-epa-us-steel-reach-75-milliondeal-fix-duluth-mill-site (accessed on 24 June 2019).

Myers, J. (2018), “EPA, U.S. Steel reach $\$ 75$ million deal to fix Duluth mill site”, Duluth News Tribune, https://www.duluthnewstribune.com/news/4492023-epa-us-steel-reach-75-million- 
deal-fix-duluth-mill-site (accessed on 24 June 2019).

Nedelkoska, L. and G. Quintini (2018), “Automation, skills use and training”, OECD Social, Employment and Migration Working Papers, No. 202, OECD Publishing, Paris, http://dx.doi.org/10.1787/2e2f4eea-en.

O'Brien, M. and S. Burrows (2017), "Recycling older steelworkers: Post-redundancy job-mobility experiences of workers from BlueScope steel port Kembla”, Australian Bulletin of Labour, Vol. 43/1, pp. 21-44, https://search.informit.com.au/documentSummary; $\mathrm{dn}=595744748073891 ; \mathrm{res}=$ IELBUS (accessed on 26 June 2019).

O'Brien, M. and S. Burrows (2017), "Recycling older steelworkers: Post-redundancy job-mobility experiences of workers from BlueScope steel port Kembla”, Australian Bulletin of Labour, Vol. 43/1, pp. 21-44, https://search.informit.com.au/documentSummary; $\mathrm{dn}=595744748073891 ; \mathrm{res}=$ IELBUS (accessed on 26 June 2019).

OECD (2019), OECD Employment Outlook 2019: The Future of Work, OECD Publishing, Paris, https://dx.doi.org/10.1787/9ee00155-en.

OECD (2018), Good jobs for all in a changing world of work : the OECD jobs strategy., OECD Publishing, Paris,, https://doi.org/10.1787/9789264308817-en.

OECD (2018), Good jobs for all in a changing world of work: The OECD jobs strategy, OECD, internal working document [C(2018)34].

OECD (2018), OECD Employment Outlook 2018, OECD Publishing, Paris, https://dx.doi.org/10.1787/empl outlook-2018-en.

OECD (2018), STATE ENTERPRISES IN THE STEEL SECTOR, https://doi.org/10.1787/2a8adgcd-en (accessed on 20 January 2020).

OECD (2018), Structural Adjustment, Mass Lay-offs, and Employment Reallocation, OECD internal document.

OECD (2016), Unclassified DSTI/SU/SC(2015)8/FINAL Organisation de Coopération et de Développement Économiques Organisation for Economic Co-operation and Development DIRECTORATE FOR SCIENCE, TECHNOLOGY AND INNOVATION STEEL COMMITTEE CAPACITY DEVELOPMENTS IN THE WORLD STEEL INDUSTRY JTO339366o, https://one.oecd.org/document/DSTI/SU/SC(2015)8/FINAL/en/pdf.

OECD (2015), OECD Digital Economy Outlook 2015, OECD Publishing, Paris, https://dx.doi.org/10.1787/9789264232440-en.

OECD (2015), PUBLIC FINANCIAL SUPPORT TO NEW INVESTMENTS IN THE GLOBAL STEEL INDUSTRY: WORK IN PROGRESS, https://one.oecd.org/document/DSTI/SU/SC(2015)2/REV1/en/pdf.

OECD (2015), The Future of Productivity, OECD Publishing, Paris, https://dx.doi.org/10.1787/9789264248533-en. 
OECD (2014), Calculating Summary Indicators of EPL Strictness: Methodology, OECD, Paris, http://www.oecd.org/els/emp/EPL-Methodology.pdf (accessed on 20 June 2019).

OECD (2008), Steel Industry Restructuring and Employment, OECD, https://one.oecd.org/document/DSTI/SU/SC(2008)32/en/pdf.

OECD (2005), "Sectoral Case Studies", in Trade and Structural Adjustment/ Embracing Globalisation, https://one.oecd.org/\#/publication/g1gh5abd/en? k=s6uld6.

OECD (2002), UNITED STATES REPORT FOR THE INTER GOVERNMENTAL PEER REVIEW ON CAPACITY AND INDUSTRY RESTRUCTURING, https://one.oecd.org/document/SG/STEEL(2002)20/12/en.

OECD (1999), Co-operation between OECD and Russian and Ukraine in the Steel Sector, https://one.oecd.org/document/CCNM/NIS/DSTI(99)45/en/pdf.

O’leary, C. (2010), “Policies for Displaced Workers: An American Perspective”, http://dx.doi.org/10.17848/wp10-170.

Pavcnik, N. (2002), "Trade Liberalization, Exit, and Productivity Improvements: Evidence from Chilean Plants", The Review of Economic Studies, Vol. 69/1, pp. 245-276, http://dx.doi.org/10.1111/1467-937X.00205.

Pindyck, R. (2008), Sunk Costs and Real Options in Antitrust Analysis, ABA Section of Antitrust Law, http://web.mit.edu/rpindyck/www/Papers/Vol.\%20IChap.\%2026CompetitionLaw m1.pdf (accessed on 17 June 2019).

Pindyck, R. (n.d.), SUNK COSTS AND REAL OPTIONS IN ANTITRUST ANALYSIS, http://web.mit.edu/rpindyck/www/Papers/Vol.\%20IChap.\%2026CompetitionLaw m1.pdf (accessed on 17 June 2019).

Poschke and Markus (2009), "Employment protection, firm selection, and growth", Journal of Monetary Economics, Vol. 56/8, pp. 1074-1085, https://ideas.repec.org/a/eee/moneco/v56y2009i8p1074-1085.html (accessed on 25 June 2019).

Rapoport, E. (2014), The Politics Of Disinvestment And Development In Gary, Indiana, pp. 20-26, http://ssa.uchicago.edu/ (accessed on 25 June 2019).

Restuccia, D. and R. Rogerson (2013), "Misallocation and productivity", Review of Economic Dynamics, Vol. 16/1, pp. 1-10, http://dx.doi.org/10.1016/j.red.2012.11.003.

Rosenbaum, D. and F. Lamort (1992), "Entry, barriers, exit, and sunk costs: an analysis", Applied Economics, Vol. 24/3, pp. 297-304, http://dx.doi.org/10.1080/00036849200000142.

Santos, E. (2017), “Externalities from FDI on domestic firms' productivity: A Literature Review for Developed Countries Externalities from FDI on Domestic Firms' Productivity: A Literature Review for Developed Countries", No. 88958, University of Coimbra - Faculty of Economics, Coimbra, https://mpra.ub.uni-muenchen.de/88958/1/MPRA paper 88958.pdf (accessed on 25 June 2019). 
Shabecoff, P. (1979), U.S. Steel Will Spend \$40o Million In $3^{1 / 2}$ Years on Pollution Cleanup nytimes 1979 - Google Search, New York Times, https://www.google.com/search?rlz=1C1GCEA enFR844FR844\&ei=nSsTXd2RGuaGjLsPasiAs\&q=U.S.+Steel+Will+Spend $+\% 24400+$ Million+In+3\%C2\%BD+Years+on+Pollution+Cle anup+nytimes+1979\&oq=U.S.+Steel+Will+Spend+\%24400+Million+In+3\%C2\%BD+Years+on + Pollution+Cleanup+nytim (accessed on 26 June 2019).

Silva, F. (2016), OECD stuctural adjustment Mass Layoffs and employment - Google Search, OECD, https://www.google.com/search?rlz=1C1GCEA enFR844FR844\&ei=cS8TXbK7BMjoaImbhvg $\underline{M} \& q=O E C D+$ stuctural+adjustment + Mass + Layoffs + and + employment\&oq=OECD + stuctural $+\mathrm{a}$ djustment+Mass+Layoffs+and+employment\&gs_l=psy-

ab.3..33i10i21j33i10i16ol2.10980.18995..19077...0.0..1 (accessed on 26 June 2019).

Silva, F. et al. (2019), "Structural adjustment, mass lay-offs and employment reallocation", OECD Science, Technology and Industry Policy Papers, No. 72, OECD Publishing, Paris, https://dx.doi.org/10.1787/9ob572f3-en.

Snyder, L., N. Miller and R. Stavins (2003), "The Effects of Environmental Regulation on Technology Diffusion: The Case of Chlorine Manufacturing", The American Economic Review, Vol. 93/2, pp. 431-435, https://pubs.aeaweb.org/doi/pdfplus/10.1257/000282803321947470 (accessed on 17 June 2019).

Steel on the net (2019), 2019 steelmaking cost model bof basic oxygen furnace route, https://www.steelonthenet.com/cost-bof.html (accessed on 3 July 2019).

Steel on the net (2018), Steel industry portal - Plant and Equipment Cost Information, Steel on the Net, https://www.steelonthenet.com/capital-investment/ (accessed on 24 June 2019).

Stock, W. (1998), Local Industry Employment Share and the Experiences of Displaced Workers, Industrial Relations, https://papers.ssrn.com/sol3/papers.cfm?abstract_id=142549 (accessed on 17 June 2019).

Stock, W. (1998), Local Industry Employment Share and the Experiences of Displaced Workers, Industrial Relations, https://papers.ssrn.com/sol3/papers.cfm?abstract id=142549 (accessed on 17 June 2019).

Stock, W. (1998), "Local IndustryEmployment Share and the Experiences of Displaced Workers", Industrial Relations, Vol. 37/4, pp. 478-498, http://dx.doi.org/10.1111/0019-8676.00100.

tudies, N. and U. 2002 (n.d.), "Trade liberalization, exit, and productivity improvements: Evidence from Chilean plants", academic.oup.com, https://academic.oup.com/restud/articleabstract/69/1/245/1584480 (accessed on 25 June 2019).

Studies, N. and U. 2002 (n.d.), “Trade liberalization, exit, and productivity improvements: Evidence from Chilean plants", academic.oup.com, https://academic.oup.com/restud/articleabstract/69/1/245/1584480 (accessed on 25 June 2019).

Sullivan, D. and T. Wachter (2009), "Job Displacement and Mortality: An Analysis Using Administrative Data”, Quarterly Journal of Economics, Vol. 124/3, pp. 1265-1306, http://dx.doi.org/10.1162/qjec.2009.124.3.1265. 
Syverson, C. (2011), "What Determines Productivity?”, Journal of Economic Literature, Vol. 49/2, [2 pp. 326-365, http://dx.doi.org/10.1257/jel.49.2.326.

Tang, M. and Z. Zannetos (1986), "Entry and Exit in the Steel Industry”, Sloan School of Management, https://pdfs.semanticscholar.org/40b5/714d40d4755c0517doa24308ab15f43a2coe.pdf (accessed on 26 February 2019).

Tang, M. and Z. Zannetos (1986), "Entry into and exit from the U.S. steel industry", https://dspace.mit.edu/bitstream/handle/1721.1/47501/entryintoexitfroootang.pdf?sequence= 1\&isAllowed $=\mathrm{y}$ (accessed on 17 June 2019).

Tirole, J. (1988), The theory of industrial organization, MIT Press, https://mitpress.mit.edu/books/theory-industrial-organization (accessed on 17 June 2019).

U.S. Department of Labor (2020), National Dislocated Worker Grants, https://www.dol.gov/agencies/eta/dislocated-workers (accessed on 23 April 2020).

U.S. Department of Labor (2020), Rapid Response Services, https://www.dol.gov/agencies/eta/layoffs (accessed on 23 April 2020).

U.S. Department of Labour (2020), Trade Adjustment Assistance for Workers, https://www.dol.gov/agencies/eta/tradeact (accessed on 23 April 2020).

Upward, R. and P. Wright (2019), “Don't Look Down: The Consequences of Job Loss in a Flexible Labour Market”, Economica, Vol. 86/341, pp. 166-200, http://dx.doi.org/10.1111/ecca.12254.

Upward, R. and P. Wright (2019), “Don't Look Down: The Consequences of Job Loss in a Flexible Labour Market”, Economica, Vol. 86/341, pp. 166-200, http://dx.doi.org/10.1111/ecca.12254.

US Environmental Protection Agency, O. (1980), What is Superfund?, Superfund, https://www.epa.gov/superfund/what-superfund (accessed on 24 June 2019).

US Environmental Protection Agency, O. (1980), What is Superfund?, Superfund, https://www.epa.gov/superfund/what-superfund (accessed on 24 June 2019).

USITC (2017), Evaluations of the Trade Adjustment Assistance Program for Workers: A Literature Review, U.S. International Trade Commission, https://www.usitc.gov/publications/332/executive briefings/ebot taaevaluationsguthlee.pdf (accessed on 28 March 2018).

Von Wachter, T., J. Song and J. Manchester (2009), Long-Term Earnings Losses Due to Mass Layoffs During the 1982 Recession: An Analysis Using U.S. Administrative Data from 1974 to 2004, Mimeo, https://www.iza.org/conference files/ESSLE2009/wachter t964.pdf.

Wharton Econometrics (1987), "Restructuring and Revival: The World Steel Industry 1987-2000", Wharton Econometrics, Vol. 111/11.

Winter- Ebmer, R. (2006), "Coping with a structural crisis: evaluating an innovative redundancyretraining project”, International Journal of Manpower, Vol. 27/8, pp. 700-721, http://dx.doi.org/10.1108/01437720610713512. 
Winter- Ebmer, R. (2006), "Coping with a structural crisis: evaluating an innovative redundancyretraining project”, International Journal of Manpower, Vol. 27/8, pp. 700-721, http://dx.doi.org/10.1108/01437720610713512.

Worldsteel (n.d.), World Steel in Figures 2019 now available | worldsteel, 2019, https://www.worldsteel.org/media-centre/press-releases/2019/world-steel-in-figures2019.html (accessed on 3 July 2019).

Yamawaki, H. (1984), “Market structure, capacity expansion, and pricing: A model applied to the Japanese iron and steel industry", International Journal of Industrial Organization, Vol. 2/1, pp. 29-62, http://dx.doi.org/10.1016/0167-7187(84)90032-8.

Yang, Q., X. Hou and L. Zhang (2018), "Measurement of natural and cyclical excess capacity in China's coal industry”, Energy Policy, Vol. 118, pp. 270-278, http://dx.doi.org/10.1016/J.ENPOL.2018.03.052. 